\title{
戦略的創造研究推進事業 CREST 研究領域
}

「先端光源を駆使した光科学・光技術の融合展開」

\section{研究課題}

「高強度テラヘルツ光による究極的分光技術開拓と物性 物理学への展開」

\section{研究終了報告書}

研究期間 平成 21 年 10 月～平成 27 年 3 月

\author{
研究代表者:田中耕一郎 \\ (京都大学大学院理学研究科・教授)
}




\section{$\S 1$ 研究実施の概要}

(1) 実施概要

本研究はフェムト秒レーザーをもちいた高強度テラヘルツ光発生技術を高度化し、究極的な テラヘルツ分光技術の開拓とその物性物理学や生命科学への展開を目的とした。そのために、 京都大学、広島大学、早稲田大学、オリンパス(株)からなる研究チームを構成し、研究をす寸 めた。高強度テラヘルツ光源として、シングルサイクルパルスの超短パルステラヘルツ光源と数

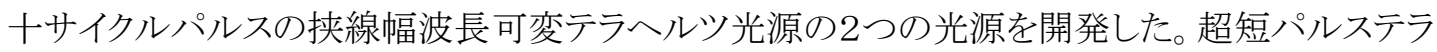
ヘルツ光源をもちいて、半導体における超高速伝導現象や非線形光学応答に関して新奇な現 象を発見した。また、これまでにない実時間で動作するテラヘルツ近接場顕微鏡の開発をおこ ない、様々なデバイスや材料、生細胞の時空間テラヘルツ電磁場イメージングに成功した。さら に、数十サイクルパルスの挟線幅波長可変テラヘルツ光源をもちいて、半導体の電子励起状 態の非摂動領域の光学現象を見いだした。これらの研究成果を、原著論文 (欧文誌) 38件、国 際学会招待講演43件、国際学会口頭発表37件によって発表するとともに、付随して得られた 知的財産を確保した (国内特許出願: 11 件、国際特許出願: 1件)。また、本研究プロジェクトの 成果を対象に8件の表彰を受けるなど、内外から高い評価をうけた。以上のように、新規に開発 した高強度テラヘルツ光源によって、これまでに見られなかったような非線形光学応答の発見 やテラヘルツ近接場顕微鏡の構築に成功し、物性物理学へ大きな展開を示せたことから、当初 の研究目的は達成された。以下では、特筆すべき成果を列挙する。

1. 京都大学グループにおいて中心周波数 $1 \mathrm{THz}$ で $1 \mathrm{MV} / \mathrm{cm}$ 以上の電場強度をもつシングル サイクルパルスの高強度テラヘルツ光の発生に成功した(原著論文 6 )。これは、開発時点で世 界最高の性能を示しており、高く評価された。

2. 上記のシングルサイクルテラヘルツパルス光を広島大学グループで作製した半導体量子井 戸に照射することにより、1000倍以上のキャリア増幅が1ピコ秒以内に生じることを明らかにし た(原著論文9)。また、金属構造体によってさらなる電場増強をおこなったテラヘルツ光を半導 体に照射することにより、ゼナートンネル効果を誘起することに成功した。これらの結果は「限界 光駆動半導体物理」とでも呼ぶべき学術分野の先駆けである。

3. 早稲田大学グループで基礎的な開発をおこなった挟線幅波長可変テラヘルツ光源を京都 大学グループが高強度化することによって、高強度波長可変テラヘルツ光源を実現した。この テラヘルツ光の照射により、半導体量子井戸の励起子状態において非摂動論領域の巨大な非 線形光学応答が生じることを明らかにした。

4. 空気プラズマをもちいたシングルサイクルパルスの高強度テラヘルツ光により高電場下にお けるグラフェン中の電子ダイナミクスをサブピコ秒の時間分解能で明らかにした。キャリアが熱化 する以前の超高速な輸送特性のミクロスコピックなメカニズムを明らかにすることに成功し、グラ フェンのデバイス化に向けた基礎を固めた(原著論文19)。

5. 京都大学グループとオリンパス(株)の共同研究により、波長の 1/100 以下の空間分解能を もち、ビデオレートで実時間動作するテラヘルツ近接場顕微鏡を構築した（原著論文 $2 、 8 、 11 、$ 30)。テラヘルツ金属構造体デバイスや小さい結晶の電磁場応答を近接場の領域で解析可能 であることを示した(原著論文18、35)。広島大学グループで開発したホーンアンテナをもちい たカップラ一の電磁場解析にも威力を発揮し、テラヘルツデバイス構築のために強力な手段で あることを示すことができた(原著論文26)。

6. 京都大学グループとオリンパス(株)の共同研究により、テラヘルツ近接場顕微鏡により生細 胞の観察が可能であることを示した。特に、脂肪細胞においては位相イメージングが有効であ ることを明らかにした。 
(2) 顕著な成果

＜優れた基礎研究としての成果 $>$

1. 世界最高電場強度を有するテラヘルツシングルサイクル光源の開発に成功

H. Hirori, A. Doi, F. Blanchard, and K. Tanaka, "Single-cycle terahertz pulses with amplitudes exceeding $1 \mathrm{MV} / \mathrm{cm}$ generated by optical rectification in $\mathrm{LiNbO}_{3}$ ", Appl. Phys. Lett. 98, 091106 (2011).（原著論文 6)

被引用件数： 164 件 (WEB OF SCIENCE)、 232 件 (Google Scholar)

概要:フェム卜秒パルスレーザーの $\mathrm{LiNbO}_{3}$ 結晶内部での光整流過程を用いることによって、

$1 \mathrm{MV} / \mathrm{cm}$ の電場振幅を超える、世界最高強度のテラヘルツパルス光源の開発に初めて成功 した。その集光強度は他のグループが開発した光源に比べて数十倍という強さに達し、国内 外の多くの研究者によって同手法が採用されるなど、この分野で世界的なインパクトを与え た。

2. 高強度テラヘルツパルスの照射により半導体キャリアの1000倍にもおよぶ増幅に成功

H. Hirori, K. Shinokita, M. Shirai, S. Tani, Y. Kadoya, K. Tanaka, "Extraordinary carrier multiplication gated by a picosecond electric field pulse", Nature Communications, 2, 594 (2011). (原著論文 9)

被引用件数： 42 件 (WEB OF SCIENCE)、 65 件 (Google Scholar)

概要: 高強度テラヘルツ光パルスを半導体試料 (GaAs/AlGaAs 多重量子井戸)に照射するこ とにより、量子井戸内の初期キャリアの約 1000 倍にも及ぶ巨大なキャ少アの増幅に伴う、試料 からの発光の観測に成功した。ピコ秒といら瞬間的な高電場下では、キャリアは散乱のない弾 道的運動をし、効率的な衝突イオン化を介したキャリア増幅を実現出来ることを示しており、今 後の高強度電場下で動作する超高速半導体デバイスの新しい可能性として注目された。

3. 高強度テラヘルツパルスの照射によるグラフェンの超高速輸送現象の解明

Shuntaro Tani, Francois Blanchard, and Koichiro Tanaka "Ultrafast Carrier Dynamics Under High Electric Field in Graphene", Phys. Rev. Lett. 109, 166603 (2012)。（原著論文 19）

被引用件数： 36 件 (WEB OF SCIENCE)、 54 件 (Google Scholar)

概要：グラフェンは室温で銀に匹敵する伝導度を持ち、次世代ナノデバイスの基幹材料として 脚光を浴びている。本成果では高電場下におけるグラフェン中の電子ダイナミクスをサブピコ 秒の時間分解能で明らかにした。より長いパルス幅を用いた類似研究に比べ大気プラズマ光 源を用いた高強度テラヘルツパルスを用いることで、キャリアが熱化する以前の超高速な輸送 特性のミクロスコピックなメカニズムを明らかにすることに成功し、グラフェンのデバイス化に向 けた基礎を固めた。

＜科学技術イノベーションに大きく寄与する成果 $>$

1. テラヘルツデバイス評価に資するテラヘルツ顕微鏡の開発

概要: 高強度テラヘルツ発生技術とレーザー走査型顕微鏡製品をベースとした実用的な $\mathrm{THz}$ 近接場顕微鏡装置を開発した。波長の 100 分の 1 以下である $10 \mu \mathrm{m}$ の空間分解能をもち実 時間で動作する顕微鏡は、電磁場シミュレーションに頼っていた近接場領域の電磁場応答を 解析する新しいプラットフォームを提示した。メタマテリアル等の回折限界以下の微小デバイ スの実評価から、世界初となる生細胞観察まで、様々なアプリケーションの可能性を示した。 装置としてのコンセプトはほぼ完成しており、アプリケーション探索のステージに本技術を発展 させた意義は大きい。

2. 金属構造体をベースとしたセンシング技術の先鋭化

概要:金属構造体を用いることで、特定周波数のテラヘルツ電場や磁場を増強できることを明 らかにした。この増強は、金属構造体周辺のテラヘルツ光の波長よりずっと小さい空間スケー 
ルの「特別な場所」において生じていることから(近接場増強)、可視域の光をもちいたテラへ ルツセンシングと組み合わせることにより、様々な周波数のテラヘルツ電場応答や磁場応答を 空間的に切り分けて計測することが可能である。本 CREST 研究では、その原理を近接場顕 微鏡や類似の計測技法を用いて明らかにし、金属構造体を用いたテラヘルツセンシング技術 の先鋭化に寄与した。これにより、高速で多自由度の計測が可能となる新たなテラヘルツセン シングデバイスの道が拓かれる可能性がある。

3. フェムト秒レーザーをベースとした高強度テラヘルツ発生装置の開発

概要: 高強度フェム卜秒パルスレーザーとパルス波面傾斜技術を駆使して、 $\mathrm{LiNbO}_{3}$ 結晶の光 整流過程による高強度テラヘルツ光発生装置の構築に成功した。光学系の最適化をおこなう ことによって、1 MV/cm の電場振幅を超える、世界最高強度のテラヘルツパルス光源の開発 に初めて成功した。その集光強度は他のグループが開発した光源に比べて数十倍といら強さ に達し、国内外の多くの研究者によって同手法が採用されるなど、この分野で世界的なインパ クトを与えた。

\section{$\S 2$ 研究実施体制}

(1) 研究チームの体制について

(1)「京都大学」グループ

研究参加者

\begin{tabular}{|c|c|c|c|}
\hline 氏名 & 所属 & 役職 & 参加時期 \\
\hline 田中 耕一郎 & 京都大学大学院理学研究科 & 教授 & H.21.10 \\
\hline 廣理 英基 & 京都大学物質一細胞統合システム拠点 & $\begin{array}{c}\text { 特定拠点 } \\
\text { 准教授 }\end{array}$ & Н.21.10 \\
\hline 有川 敬 & 京都大学大学院理学研究科 & 助教 & H.25. $4 \sim$ \\
\hline 田中智子 & 京都大学物質一細胞統合システム拠点 & 研究員 & H.22. $1 \sim$ \\
\hline 玉谷 知裕 & 京都大学大学院理学研究科 & 研究補助員 & H.26. $4 \sim$ \\
\hline Christian Wolpert & 京都大学物質一細胞統合システム拠点 & 研究員 & H.25. $4 \sim$ \\
\hline 谷 峻太郎 & 京都大学物質一細胞統合システム拠点 & 研究員 & H.21.10 \\
\hline 雙木 満 & オリンパス株式会社 治療技術開発部 & 課長 & $\mathrm{H} 21.10 \sim \mathrm{H} 26.3$ \\
\hline 土井 厚志 & オリンパス株式会社 光学技術部 & 課長代理 & $\mathrm{H} 21.10 \sim \mathrm{H} 26.3$ \\
\hline 蔉輪陽介 & 京都大学物質一細胞統合システム拠点 & 研究員 & $\mathrm{H} 22.4 \sim \mathrm{H} 23.3$ \\
\hline $\begin{array}{c}\text { Francois } \\
\text { Blanchard }\end{array}$ & 京都大学物質一細胞統合システム拠点 & 特定研究員 & $\mathrm{H} 21.10 \sim \mathrm{H} 24.9$ \\
\hline 青木 隆朗 & 京都大学大学院理学研究科 & 特定准教授 & $\mathrm{H} 21.10 \sim \mathrm{H} 23.3$ \\
\hline 白井 正伸 & 京都大学物質一細胞統合システム拠点 & 特定助教 & $\mathrm{H} 21.10 \sim \mathrm{H} 24.3$ \\
\hline Nicolas Moisan & 京都大学物質一細胞統合システム拠点 & 特定研究員 & $\mathrm{H} 21.10 \sim \mathrm{H} 22.10$ \\
\hline
\end{tabular}




\begin{tabular}{|l|l|l|l|}
\hline 永井 正也 & 京都大学大学院理学研究科 & 助教 & H21.10 H22.11 \\
\hline
\end{tabular}

研究項目

・ 波長可変高強度テラヘルツ光源開発

・ 半導体量子構造における非線形分光

・リアルタイムテラヘルツ近接場顕微鏡の開拓と応用

(2)「広島大学」グループ

研究参加者

\begin{tabular}{|c|c|c|c|}
\hline 氏名 & 所属 & 役職 & 参加時期 \\
\hline 角屋 豊 & 広島大学大学院先端物質科学研究科 & 教授 & $\mathrm{H} 21.10 \sim$ \\
\hline 北川 二郎 & 広島大学大学院先端物質科学研究科 & 助教 & $\mathrm{H} 21.10 \sim \mathrm{H} 24.3$ \\
\hline 富永 依里子 & 広島大学大学院先端物質科学研究科 & 助教 & $\mathrm{H} 24.8 \sim$ \\
\hline 田口 玄 & 広島大学大学院先端物質科学研究科 & 研究員 & $\mathrm{H} 22.4 \sim \mathrm{H} 23.3$ \\
\hline Damien Armand & 広島大学大学院先端物質科学研究科 & 研究員 & $\mathrm{H} 22.6 \sim$ \\
\hline
\end{tabular}

研究項目

・ 半導体量子構造における非線形分光とテラヘルツスイッチ

・テラヘルツ非線形性発現に適した半導体量子メ夕構造

(3)「早稲田大学」グループ

研究参加者

\begin{tabular}{|c|c|c|c|}
\hline 氏名 & 所属 & 役職 & 参加時期 \\
\hline 青木 隆朗 & 早稲田大学理工学術院 & 教授 & $\mathrm{H} .23 .4 \sim$ \\
\hline 㝨輪 陽介 & 大阪大学大学院基礎工学研究科 & 助教 & H.23.4 \\
\hline
\end{tabular}

研究項目

・ 波長可変高強度テラヘルツ光源開発

・微小共振器一量子ドット結合系のテラヘルツ精密分光とコヒーレント制御

(2) 国内外の研究者や産業界等との連携によるネットワーク形成の状況について

高強度シングルサイクルテラヘルツ光源をもちいた非線形光学研究に関しては、東京大学、大阪 大学、MIT(米)、レーゲンスブルグ大学(独)、コンスタンツ大学(独)、Max-Plank 研究所(独)な どと情報交換や共同研究を活発に推進した。このネットワーク形成の成果として、Nature

Photonics 誌に共同で書いたReview Paper(原著論文 22)がある。テラヘルツ顕微鏡に関しては、 オリンパス(株)やアイシン精機(株)と共同研究を進めるとともに、同じ CREST 領域の研究者と共 同研究を進めた。 


\section{$\S 3$ 研究実施内容及び成果}

I.「京都大学」グループ

\section{1 波長可変高強度テラヘルツ光源開発}

(1)研究のねらい

現在のシングルサイクル高強度テラヘルツ光発生技術を発展させ、共鳴効果を測定可能な、 高強度波長可変テラヘルツ光源 (帯域: 0.5-2.5 THz, スペクトル幅 $100 \mathrm{GHz}$ 以下, ピーク電 場強度：100kV/cm)を開発する。摂動論ではとりあつかうことが不可能な領域の非線形分光、 テラヘルツ近接場顕微鏡への適用を目指す。

(2)研究実施方法

新奇な非線形光学現象の発現が期待される、シングルサイクル高強度テラヘルツ光の最適 化を追加項目として優先し、波長可変化を 2 年間繰り下げる計画変更をおこなった。シングル サイクル高強度テラヘルツ光の光源開発は京都大学グループがおこない、波長可変光源開 発は京都大学グループと早稲田大学グループの共同研究です寸めた。

\section{(3)研究成果}

（1）シングルサイクルテラヘルツ光発生

高強度フェム卜秒パルスレーザーとパルス波面傾斜技術を駆使して、 $\mathrm{LiNbO}_{3}$ 結晶の光整流 過程による高強度テラヘルツ光発生装置を構築した。図1左のように発生光学系にイメージ光 学系を用い、発生後の集光系に3つの放物面鏡をもちいることで、世界で初めて中心周波数 $1 \mathrm{THz}$ で $1.2 \mathrm{MV} / \mathrm{cm}$ 以上の電場強度の発生に成功した。(原著論文 6 ) 図1右に得られたテ ラヘルツ光の時間波形を示す。これは計画当初に比べて、4 倍の電場増強、 16 倍の出力増
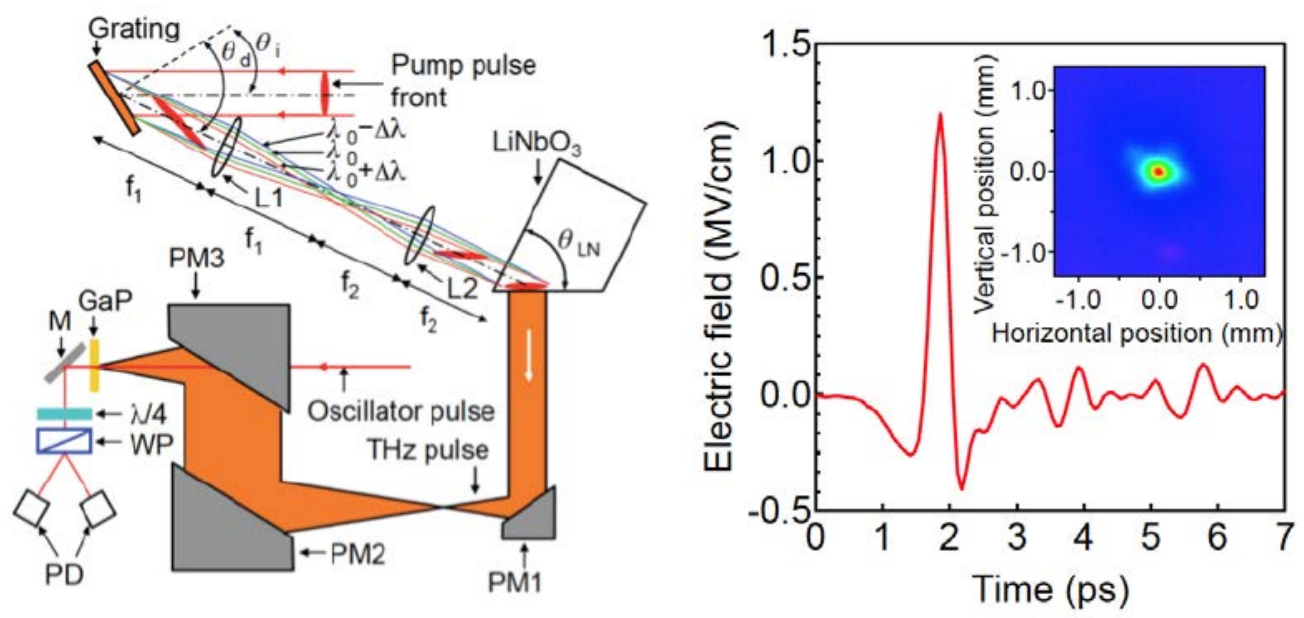

図 1 : 高強度テラヘルツ波の発生·検出の実験系の模式図 (左側)。1MV/cm 強のピーク電場を 持つ $\mathrm{THz}$ パルスの時間波形(右側)。挿入図は $\mathrm{THz}$ パルスのスポット画像。

強である。成功の最大の要因は、イメージ光学系により $\mathrm{LiNbO}_{3}$ 結晶内において入射する近 赤外光パルス面とこれを傾けるための回折格子のイメージ面の角度を一致させた点である。ま た、図1右の挿入図にあるようにテラヘルツマイクロボロメーターカメラ(NEC 製)により、テラへ ルツ波の集光の様子を実際にモニタ寸ることにより最適解を得た。これにより高効率かつ大口 径のテラヘルツの発生に成功した。これはテラヘルツマイクロボロメーターカメラの最初の実 用的なデモンストレーションとなった。

(2)空気プラズマをもちいた高強度テラヘルツ光源

空気に高強度レーザーを集光して、高強度テラヘルツ波を発生させる方法を検討した。特に、 基本波と倍波の相対位相関係および相対偏光角を制御することで、空気プラズマから発生す 
る 1-10 THz の低周波成分と 30-50 THz の高周波成分の強度と偏光を制御できることを見い だした(図 2(a))。低周波成分を最大化した場合、ピーク電場強度は約 $300 \mathrm{KV} / \mathrm{cm}$ 、パルス幅 は 200fs であり、Graphene の THz 非線形光学実験に応用した(図2(b)、原著論文 19)。
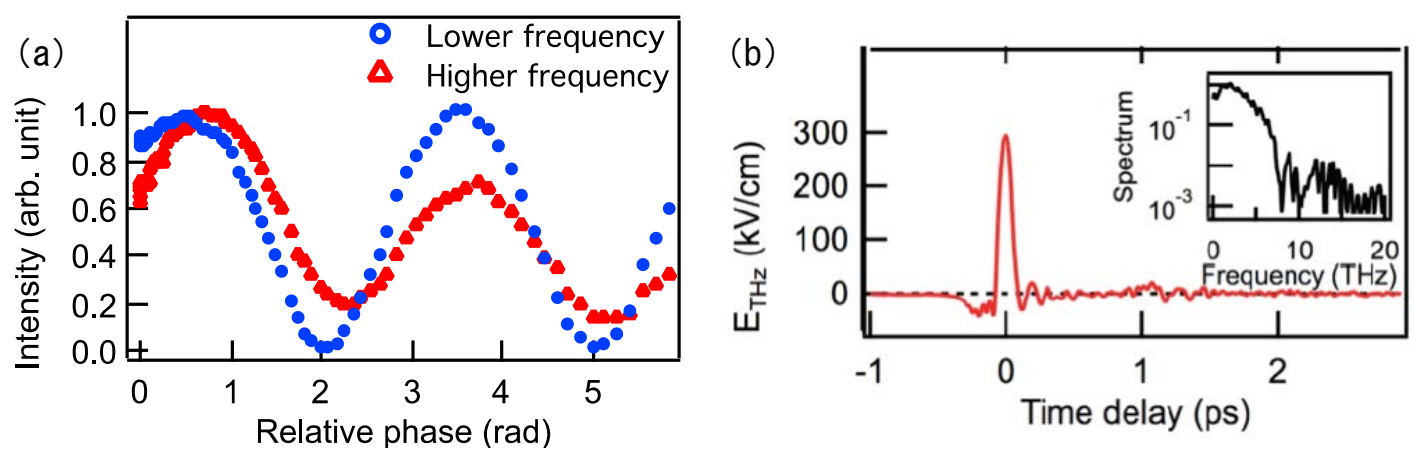

図 2: (a)プラズマ生成に用いているフェムト秒パルスの基本波と 2 倍波の相対位相に対する 1-10 THz の低周波成分強度と 30-50 THz の高周波成分強度の変化。(b) 電気光学サンプリ ングによって得られた空気プラズマによって発生したテラヘルツ光の電場波形。

(3) 波長可変高強度テラヘルツ光源開発 当初の予定から 2 年繰り下げて、早稲 田大学グループと共同で研究開発を おこなった。原理検証実験 (早稲田大 学の項を参照)ののち、当該技術を 1 -(1)で述べた高強度フェム卜秒パルス レーザーとパルス波面傾斜技術、

$\mathrm{LiNbO}_{3}$ 結晶の光整流過程による高強 度テラヘルツ光発生と組み合わせるこ とにより高強度化した。その結果、図3 のように $0.5 \mathrm{THz}-2.0 \mathrm{THz}$ の間で波 長可変であり $50 \mathrm{GHz}$ 以下の線幅と、 $10 \mathrm{kV} / \mathrm{cm}$ 以上の最大電場強度を有 する光源の構築に成功した。この光源 を用いて、半導体における非線形光学 実験をおこなった。

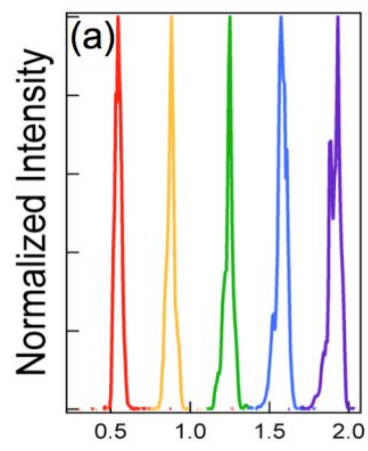

Frequency $(\mathrm{THz})$

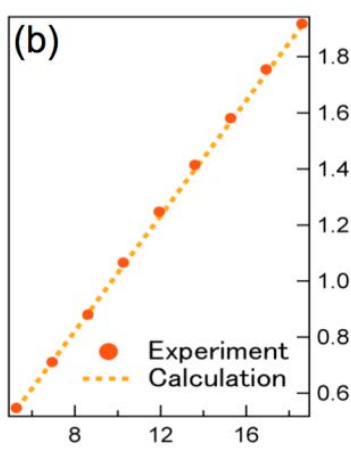

Time delay of Interferometer (ps)

図 3:(a)狭帯域テラヘルツパルスのパワースペク トル。(b) テラヘルツ周波数のマイケルソン干渉計 における時間間隔依存性。

(まとめ)

計画変更はあったものの、レーザーのパルス波形整形技術をもちいて波長可変高強度テ ラヘルツ光源を構築した。シングルサイクル高強度テラヘルツ光源開発においては、 $1 \mathrm{THz}$ 帯のテラヘルツ光として世界最高の電場強度を達成した。これらにより、テラヘルツ 非線形分光の研究が加速された。

\section{2 半導体量子構造における非線形分光}

(1)研究のねらい

テラヘルツ領域における非線形光学応答は可視光領域とは極めて異なる状況にあることが予 想される。可視域では破壊が起きるために不可能であった固体における非摂動論的非線形 光学の実験をテラヘルツ領域では破壊閾值以下の光強度で行うことが可能である。固体にお ける非摂動論的非線形光学はまったく未知の領域であり、物性物理学に新たな展開を導く可 能性が高い。本研究では、半導体量子構造における高密度電子一正孔(励起子)系やサブバ ンド構造に着目し、テラヘルツ領域の非線形分光技術を確立するとともに、非摂動論的非線 
形光学応答の問題に正面から取り組む。

(2)研究実施方法

研究項目1で開発した高強度テラヘルツ光源をもちいて、非線形光学の実験をおこなう。巨 大な非線形効果が期待される、半導体における不純物キャリア系、強誘電体のソフトモードフ オハ、、量子井戸構造の励起子系、グラフェンなどの低次元伝導体において研究を進めた。 量子井戸試料は広島大学と東京大学との共同研究により準備した。また、金属構造体による 局所電磁場増強の研究もおこなった。

(3)研究成果

(1) 半導体における不純物キャリア系のイオン化（原著論文 24）

Ga をドープした Ge において高強度テラヘルツ光を照射することによって、アクセプターに束 縛されたホールがイオン化し、自由なキャリアとして振る舞うことが観測された。図4は、5K に おいてシングルサイクルの高強度テラヘルツ光を照射した後、200 ピコ秒に十分に弱いテラ ヘルツ光をもちいて観測した $\mathrm{Ge}$ のテラヘルツ領域の伝導度(a)と誘電率(b)である。高強度テ ラヘルツ波の電場強度が 弱い場合は、アクセプター に束縛されたホールの束 縛準位間遷移のスペクトル が得られるが、電場強度が 強い場合は、ドルーデ型 の誘電応答が得られること がわかった。これは、5 $\mathrm{KV} / \mathrm{cm}$ 以上の電場強度を もつテラヘルツ光照射によ り、アクセプターがイオン 化したことを表す。DC 電 場のトンイオン化理論から 予想されるトンネルイオン 化閾值が $5 \mathrm{KV} / \mathrm{cm}$ である ことから、1ピコ秒以下のパ ルス幅のテラヘルツ光によ ってトンネルイオン化が誘

(a)

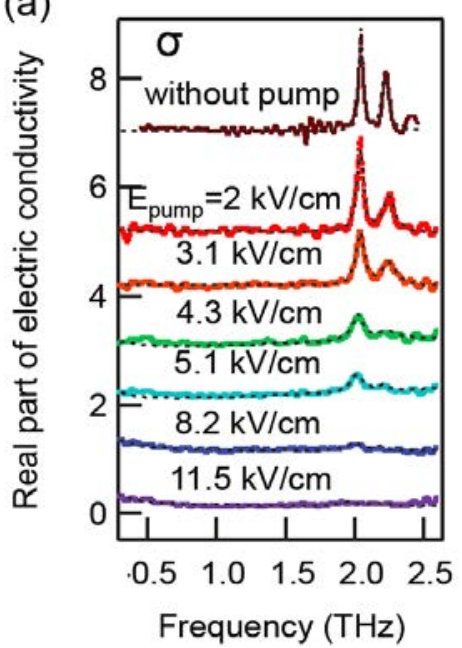

(b)

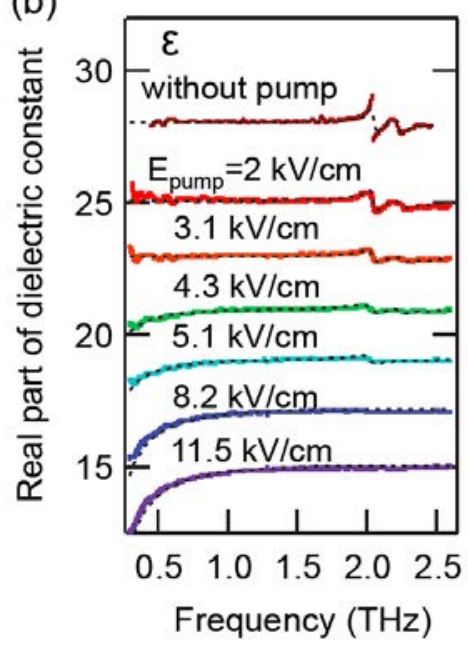

図 4:テラヘルツパルス励起後の Gaドープ Ge 試料の誘電率 スペクトル。 起されたものと考えられる。

(2)強誘電体のソフトモードフォハンの非調和性（原著論文 13）

$\mathrm{BaTiO}_{3}$ に代表される強誘電性ペロブスカイト結晶はソフト光学フォハンモー（TO フォハンモー ド)を有し、その振動数は温度の低下とともに 0 にむかって減少する。振動数の減少は静的誘 電率の増大を招き、ある温度で強誘電相転移が誘起されることとなる。このような温度変化は、 もともとの TO フォハンモードが鍋底型の非調和ポテンシャルを有していることから説明される。 本研究では、量子常誘電体として知られソフトモードを有するチタン酸ストロンチウム $\left(\mathrm{SrTiO}_{3}\right)$ の薄膜結晶に高強度テラヘルツ電場を照射し、その応答を調べることでポテンシャルの非調 和性を明らかにした。薄膜結晶を透過した電場波形をフーリエ変換し、それを印加したテラへ ルツ電場波形で割り算して得られた有効感受率の実部と虚部を図 5 に示寸 ( $\mathrm{E}_{0}$ は 80 $\mathrm{KV} / \mathrm{cm})$ 。明らかに、印加電場強度の増大とともに振幅数が高周波側にシフトしていることが わかる。これは高強度のテラヘルツ電場印可により大振幅の運動が誘起され、それにより運動 の振動数が高くなったことをあらわしている。最大電場強度におけるソフトモードの振幅は強 誘電転移に必要な原子変位の10分の1程度と見積もられている。今後、更なるテラヘルツ電 場強度の増大により、相転移を誘起することも可能になると考えられる。 


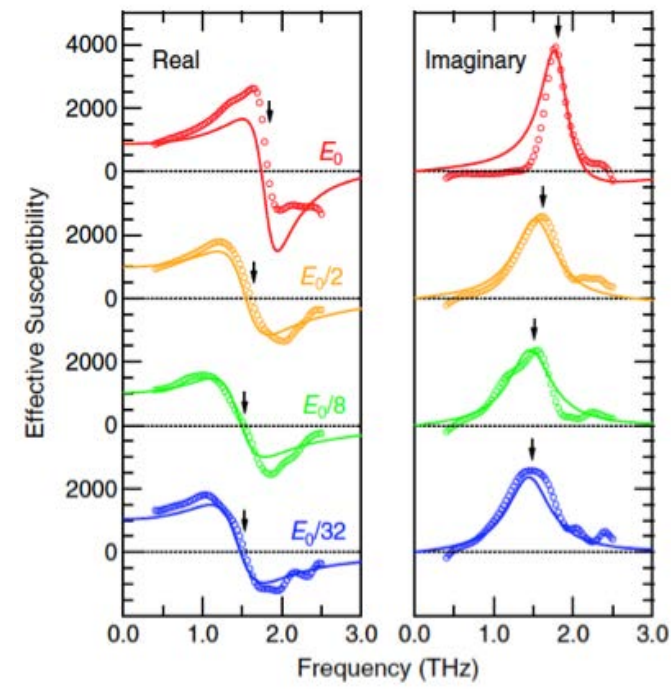

図 5: テラヘルツパルス励起後のチタン酸 ストロンチウム $\left(\mathrm{SrTiO}_{3}\right)$ 試料の誘電率スペ クトル。

(3) $\mathrm{GaAs}$ 量子井戸における巨大キャリア増幅（原著論文 9）

本研究では、 $1 \mathrm{MV} / \mathrm{cm}$ 程度のピーク電場值をも つテラヘルツ光パルスを $\mathrm{GaAs} / \mathrm{Al}_{0.3} \mathrm{Ga}_{0.7} \mathrm{As}$ 多重 量子井戸に照射し、励起 子発光 $(1.55 \mathrm{eV})$ の観測 に成功した。スペクトル形 状が可視光励起の場合 のスペクトルとほとんど一 致していることから、バン ドギャップの 380 分の 1 の光子エネルギーしかも

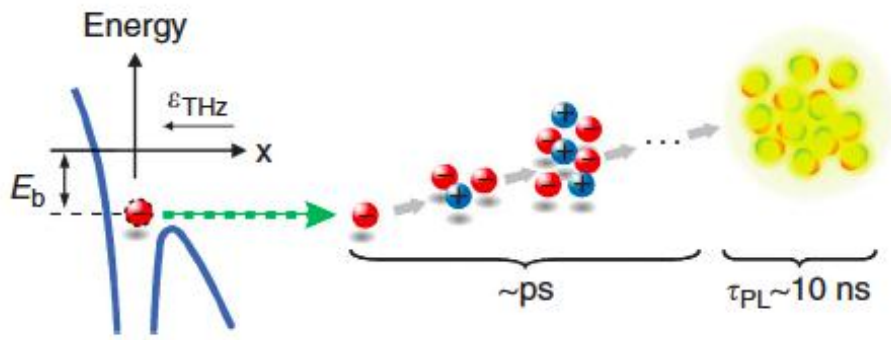

図 6:テラヘルツパルス励起により GaAs 量子井戸中の不純物 準位がイオン化し、放出された電子が衝突イオン化により増幅 し、発光する様子の模式図。

たないテラヘルツ光パルス照射によって、励 起子発光が生じたことを示している。励起子 発光は $0.45 \mathrm{MV} / \mathrm{cm}$ の電場強度以上で急激 に出現し、それより高電場では電場強度の 8 乗で増加することがわかった。発光強度は残 留キャリア密度に比べると遥かに大きいことか ら、テラヘルツ光照射により1000倍もののキ ヤリア増幅が起きていることが示唆される。こ れは、図 6 に示すように残留キャリアの加速、 インパクトイオン化などが $1 \mathrm{ps}$ 以内の短時間 に複合的に起きていることを意味している。実 際、インパクトイオン化による簡単なモデル計 算からこの結果を再現することに成功した。こ の結果は、テラヘルツ光により約 380 倍もの エネルギーのバンド間遷移を起こす世界初の 発見であり、テラヘルツ非線形分光だけでな く、半導体デバイス物理に与えるインパクトは 大きい。

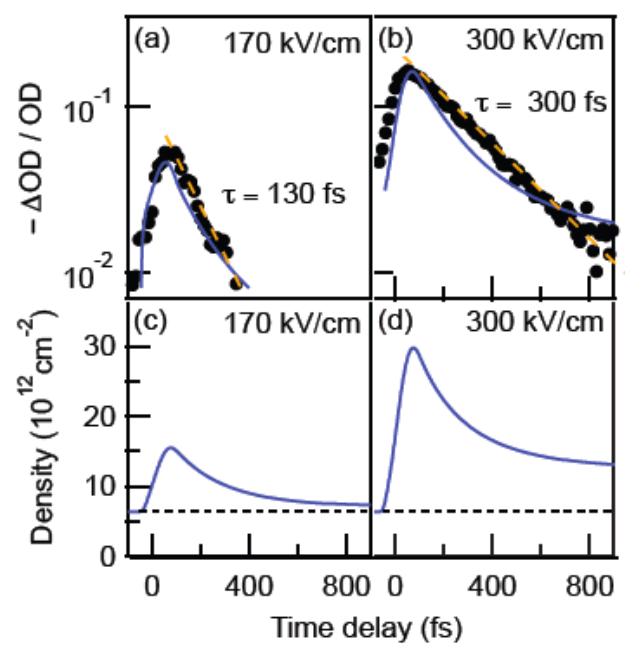

図7 : 照射テラヘルツ強度を変えた場合 の近赤外吸収飽和の時間減衰。上段は 実験、下段は理論。 
（4）グラフェンにおけるテラヘルツ誘起巨大透明化現象（原著論文 19）

大気プラズマを用いたテラヘルツ高強度テラヘルツポンプー近赤外プローブの実験系を構築 し、テラヘルツ光照射によるグラフェンの近赤外領域での $16 \%$ にもおよぶ吸収飽和を観測し た。図 7 に示寸ように、この吸収飽和は1ピコ秒以内に回復することがわかった。テラヘルツ光 のフォトンエネルギーは近赤外光の 100 分の 1 程度であることから、この吸収飽和はテラヘル ツ光により作られた極めて非摂動論的な状態を反映しているものと考えられる。このキャリアダ イナミクスを定量的に理解するため、ボルツマン方程式を用いたシミュレーションを行うことによ り実験結果を定性的に再現した。その結果、もともとのキャ少ア数の5倍以上の電子一正孔対が インパクトイオン化によって生成されることが結論された。これは、テラヘルツ領域の光による 高速可視光スイッチの構築の新しい可能性を示している。

（5）金属構造体による局所テラヘルツ電磁場増強の直接的観測 電場増強によるさらなる非線形性の発現にむけて、狭 ギャップダイポールアンテナによる電場増強を明らか にした。まずオリンパス・京都大学グループで開発さ れたテラヘルツ波顕微鏡を用いて計測を行ったが、 検出に用いる電気光学結晶基板の影響により、2倍 程度の増強度となっていたため、半導体薄膜のみを 用いた素子を作製し、励起子フランツケルディツシュ 効果を用いた観測を行った。この結果図 8 に示すよう に, 局所的かつ直接的な観測において 40 倍の増強 を実証した。また，さらに共振周波数や増強度を高め る方策を考案した。

以下の(6),(7)の研究成果は基本的にこのコンセプト を発展させたものである。

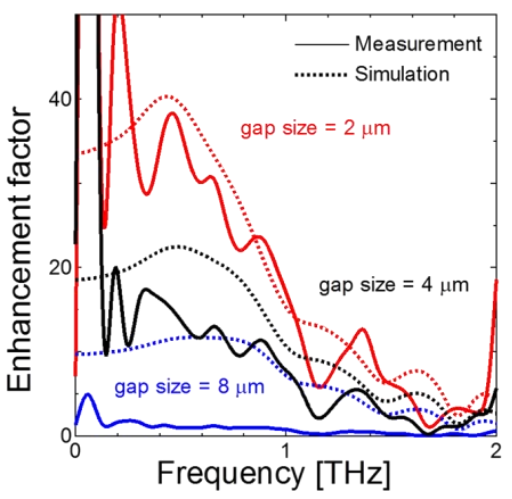

図8: 狭ギャップダイポールアンテ ナによるテラヘルツ電場増強。

(まとめ)

シングルサイクル高強度テラヘルツ光をもちいて様々な非線形光学効果を観測した。これ らの結果は、新たなキャリア伝導の物理や光スイッチに発展することが確実である。また、テ ラヘルツ電磁場増強の手段として金属構造体が有用であることを明らかにした。さらに、波 長可変テラヘルツ光源をもちいた半導体の非線形光学応答の観測にも成功した。

\section{3 リアルタイムテラヘルツ近接場顕微鏡の開拓と応用}

(1)研究の斏らい

高強度テラヘルツ光により、波長の 100 分の 1 以下の分解能を有しビデオレートで動作する 近接場顕微鏡を構築する。これにより、線形・非線形光学応答が近接場の領域で可視化され る。一般に、近接場顕微鏡の感度は低く画像取得に時間がかかるが、高強度テラヘルツ光の 特性を最大限に活用寸ることにより、高感度・高分解能・高速データ取得が可能となる。光学 系の最適化や既存の共焦点顕微鏡との融合をす寸めることにより、波長以下の大きさの固体 結晶の線形・非線形光学応答を時空間で解析可能な究極的な実験系が構築できる。また、こ のテラヘルツ近接場顕微鏡は生理環境下での生体分子や細胞の新しい可視化技術を提供 する。生体高分子などに感度があるテラヘルツ波のセンシング能力を細胞観察にまで拡張す るべく、テラヘルツ近接場顕微鏡の応用開発を行い、実際に生細胞などの試料測定を行うこ とでその効果を確認する。 
(2)研究実施方法

京都大学とオリンパスが共同で検討を行い、京都大学内にテラヘルツ近接場顕微鏡装置を 構築した。また、その装置を用いた試料測定も共同で行った。

(3)研究成果

(1)リアルタイム観察が可能なテラヘルツ近接場顕微鏡を構築し、 $\lambda / 150$ の空間分解能を達成 （原著論文 $2,8,11,30$ )

(a)

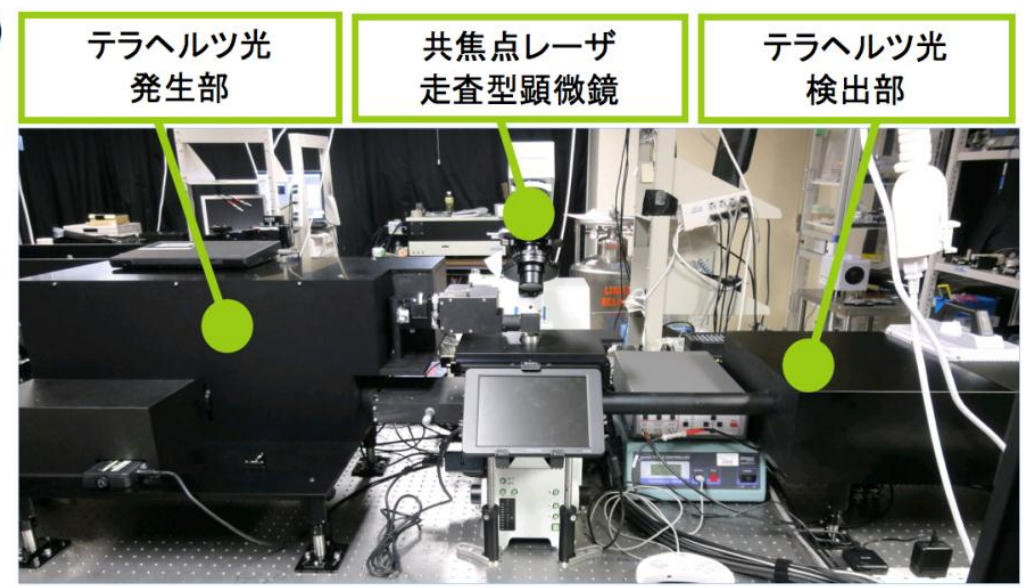

(b)
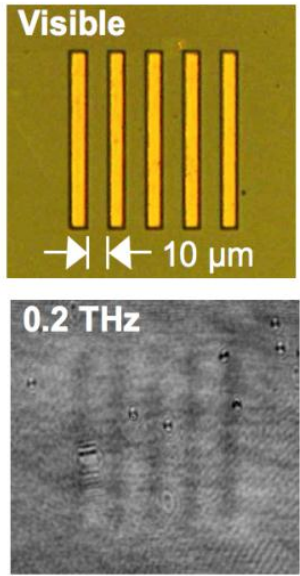

図 13: テラヘルツ近接場顕微鏡（a)全体写真、(b) 空間分解能評価画像

回折限界以下の空間分解能を有し、ビデオレートでの動作が可能なテラヘルツ近接場顕微 鏡の開発を行った。近接場検出手法を確立し、共焦点レーザー走査型顕微鏡を活用した構 成とすることで、実用に近いレベルの顕微鏡システムの構築に成功した(図 13(a))。また、図 13(b)は線幅と間隔が $10 \mu \mathrm{m}$ の金属ライン構造を可視光とテラヘルツ光で観察した結果であ るが、 $1.5 \mathrm{~mm}$ の波長 (周波数 $0.2 \mathrm{THz}$ )のテラヘルツ光でもその構造を十分に観測できてお り、波長 $(\Lambda)$ の 150 分の 1 以下の空間分解能を実現した。また、高速 CMOS カメラを利用す ることで最大 $80 \mathrm{fps}$ での画像検出も可能となった。これらの成果は論文として公表するととも に特許出願をおこなった。

(2) メタマテリアル材料の二次元電場応答を実測評価（原著論文 18）

テラヘルツ近接場顕微鏡を用いることで、これまでシミュレーションでしか検証できなかったメ タマテリアル材料における電場の時空間発展を実測で詳細に評価した。図 14 は単一スプリッ トリング共振器 (SRR)の実 測分光画像と、FDTD 計 算画像である(下記リンク にて、実測による電場時 間発展の動画を閲覧可 能)。両者は非常に近い 結果を示しており、また、 共振器ギャップ部分 (幅 4 $\mu \mathrm{m})$ でのテラヘルツ光増 幅が明瞭に観測されてい る。この検討により、テラへ ルツ近接場顕微鏡がこの ような光機能性材料の評 価に非常に有用であること を示した。
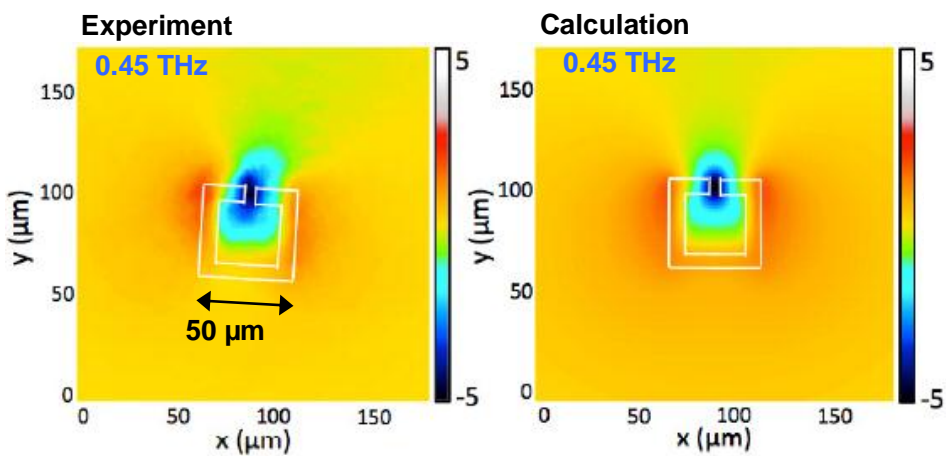

図 14: スプリットリング共振器 (SRR)のテラヘルツ光。左: 実 験で得られた $0.45 \mathrm{THz}$ 成分のテラヘルツ電場振幅画像、 右:FDTD 計算で得られた同じ周波数成分の電場振幅画像 
（3）テラヘルツ顕微鏡によるテラヘルツデバイスの評価（原著論文 26）

広島大学で作製したテラヘルツ光用ホーンアンテナの特性を、テラヘルツ近接場顕微鏡を用 いて評価した。テラヘルツ近接場顕微鏡で得た画像を周波数解析した結果、アンテナの遠方 界での測定結果と対応する周波数がアンテナ出口での近接場でのテラヘルツ電波成分とし て集中しており、アンテナがない場合と比較して約 4 倍の電場の増強がみられた。又、この測 定によりアンテナを構成する 2 つのブロックの接続部分でのテラヘルツ波のしみ出しがあるこ とが確認された。

(a)

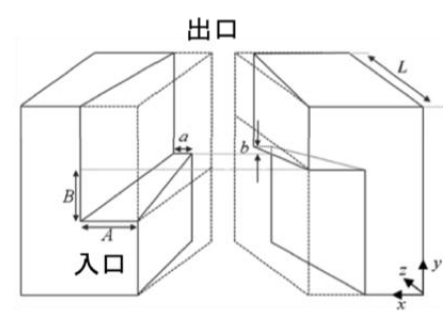

入口: $A=1.2 \mathrm{~mm}, B=1.25 \mathrm{~mm}$ 出口: $a=200 u m, b=50 u m$ 長さ: L=5mm

(b)

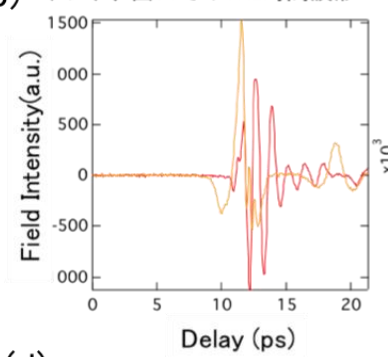

（c)アンテナ出ロでのTHZスペクトル

(d)

アンテナ出ロ面内のTHz振幅分布の時間変化

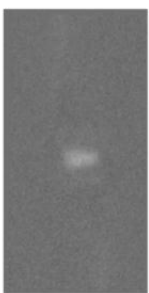

(11.63ps)

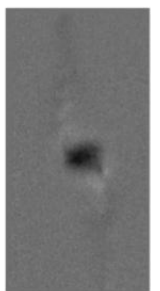

(12.11ps)

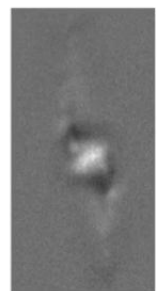

(12.54ps)

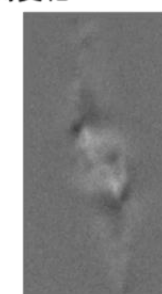

(12.92ps)

図 15 : (a)作製したホーンアンテナの形状、(b)アンテナ出ロでの THz 時間波形とアンテナがないと きの $\mathrm{THz}$ 時間波形、(c) アンテナ出ロでの $\mathrm{THz}$ スペクトルとアンテナがないときの $\mathrm{THz}$ スペクト ル、(d)アンテナ出ロでの $\mathrm{THz}$ 画像。

（4）多孔性ポリマー（Porous Coordination Polymer. PCP）におけるガス吸着過程の イメージング分析（原著論文 35）

多孔性ポリマー(Porous Coordination Polymer、PCP) は図16(b)に示すようにナノサイズ の細孔を有している結晶であり、液体にせまる密度でのガス吸着と保持が可能な材料である。 本研究では、図16(a)に示したようなリング型の共振器構造をもちいて、ガスの吸着過程をテ
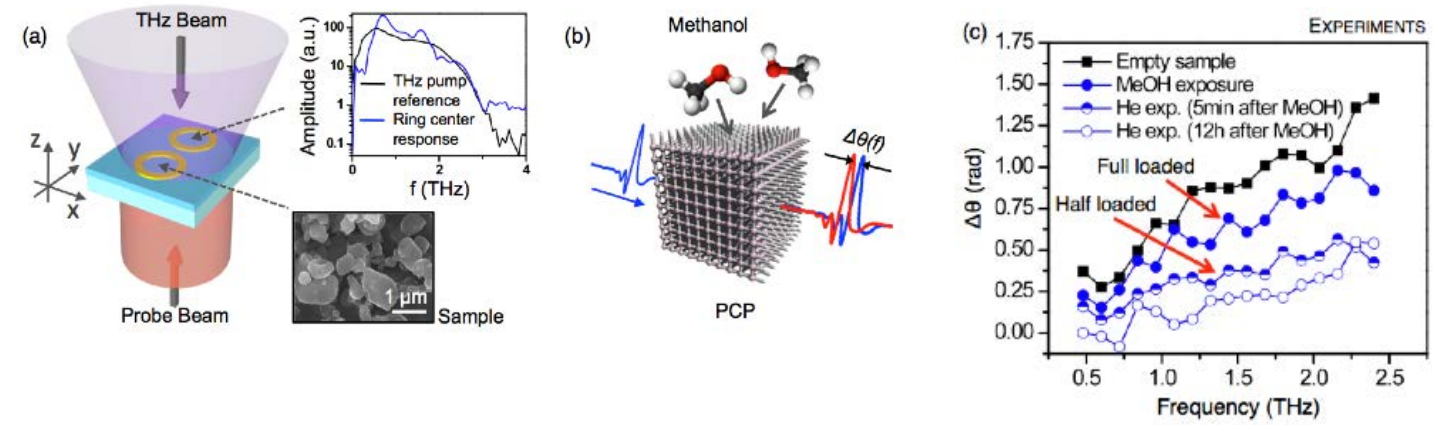

図 16:(a)作製リング型金属構造体センサーの概念図とテラヘルツ光のパワースペクトル、サンプ ルの形状。(b)PCP 結晶へのメタノールガス吸着の概念図、(c) メタノール吸着過程におけるテラ ヘルツ位相スペクトルの変化、

ラヘルツ近接場顕微鏡によってリアルタイムで分析した。リング共振器をペアで準備し、PCP を片側の共振器にだけセットすることにより、参照信号と PCP による応答を同時測定した。実 験では、PCP として $\mathrm{Cu}_{3}(\mathrm{btc})_{2}$ を用い、メタノールの吸着過程を測定した。図16(c)に示すよう 
に、テラヘルツ光応答の位相差として、メタノール量を定量評価することが可能であることがわ かった。この結果は、テラヘルツ近接場顕微鏡をデバイスリーダーとして用いた典型的な例で あり、少量の対象物に対しても高感度にテラヘルツ領域の光学応答を計測し、それをもちい たセンシングが可能であることを示している。

(まとめ)

計画通り、空間分解能が波長の $1 / 100$ 以下、実時間動作という、世界で唯一無二のテラヘルツ 近接場顕微鏡の構築に成功した。顕微鏡の応用研究も順調にす寸み、メタマテリアルや金属構造 体におけるテラヘルツ電磁場解析、生細胞などのイメージの取得に成功した。特に、生細胞の観 察は世界初の結果であり、今後の顕微鏡の応用研究の突破口となることが期待される。

\section{II.「広島大学」グループ}

\section{1 半導体量子構造における非線形分光}

(1)研究のねらい

京都大学グループの高強度テラヘルツ波よる半導体量子構造の非線形分光を行うための試 料を設計・作製する。また金属パターンを用いてテラヘルツ波を増強させる方法を探索する。

(2)研究実施方法

GaAs/AlGaAs 系半導体量子構造や2次元電子構造を分子線エピタキシ法により成長した。 必要に応じてに結晶成長層のみをエピタキシャルリフトオフ法で不要な基板から剥離し、Van der Waals 法によりサファイアまたは $\mathrm{GaP}$ 基板上ボンディングした。これらの試料に対し, 京 都大学グループでテラヘルツ波非線形分光実験が実施された。また半導体量子構造上にフ オトリソグラフィーによりダイポールアンテナ型の Au パターンを作製し、励起子フランツケルデ イツシュ効果を用いて、ギャップ部でのテラヘルツ波電界増強を調べた。

(3)研究成果

京都大学グループの項に記載（研究成果2-(3)、2-(5)、2-(9)).

\section{2 テラヘルツ非線形性発現に適した半導体量子メタ構造}

(1)研究のねらい

テラヘルツフォトニックバンド構造、メタル伝送線路、半導体量子構造を統合した半導体量子 メ夕構造を作製し、巨大な非線形光学効果を発現させることを目的とする。メタルと誘電体フォ トニック結晶からなるテラヘルツ導波路キャビティー中に半導体量子井戸を埋め込んだメタデ バイスを開発するとともに、テラヘルツ波を素子外部から効率よく結合するためのカプラーおよ び導波路内でテラヘルツを発生するための機構を開発する. 最終的には, 再生増幅を使用し ない程度の励起パルス光でテラヘルツ非線形を発現させることを目指す。テラヘルツ波非線 形応答を様々に応用寸るためには、デバイス化が重要である。特にテラヘルツ波が3次元的 に閉じ込められたキャビティーを用いることで効率化が図れ、パルス光源に再生増幅器が不 要となって, 波及効果が大きくなることが期待される。

(2)研究実施方法

研究期間の前半では、当初計画に沿ってプラズマエッチングによって作製した $\mathrm{Si}$ パターンを $\mathrm{Au}$ で覆った金属 2 次元フォトニック結晶と金属平板からなる導波路・共振器を実現した。また このデバイスにテラヘルツ波を入射するための高効率ホーンアンテナを設計・作製し, フォト ニック結晶導波路のテラヘルツ波伝搬を確認することに成功したが、この方法では低温測定 時のアライメントが極めて困難であることが判明した。このため, H25 年度から方針を変更し、 カプラー一体型テラヘルツ波共振器の実現に取り組んだ。テラヘルツ波集光と軸方向電場発 生を同時に可能にする非対称ブルズアイ構造を考案し、実証した。分子線エピタキシ結晶成 長法により作製した半導体量子井戸構造を含む金属・半導体・金属構造を、エピタキシャルリ フトオフおよびボンディングにより作製し、この中に可視プローブが可能な透明電極電極 
(ITO)からなる共振器を配置した。これらデバイスの評価には, 広島大学内のテラヘルツ分光 系、および京都大学グループで開発された、近接場顕微鏡を含む高強度テラヘルツ波光源 を用いた。

(3)研究成果

（1）フォトニック結晶・導波路・共振器（原著論文 16,17 )

数值シミュレーションに基づき種々の構成を検討した結果、フォトニック結晶としては図 20 (a),(b)に示すような正方格子金属口ッドからなる 2 次元結晶を金属平板で挟み込んだ構成と した。このデバイスにおいて、図20(c),(d)に示すように、フォトニックバンドが生成されることを 確認し、ロッドと金属平板の間のギャップを変化させることで、バンド構造を制御できることを 見出した。
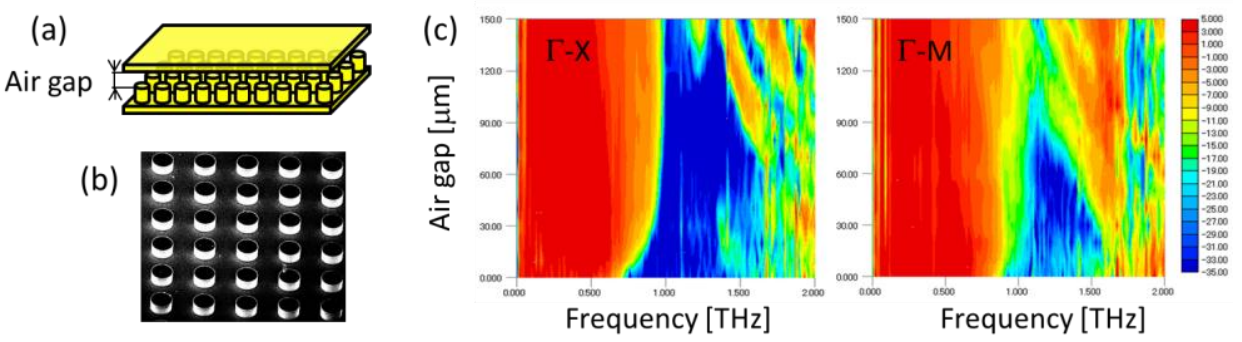

図20:フォトニック結晶。(a)概念図、(b)パターン部の顕微鏡写真、(c) $「-X$ およ び「-M 方向の透過スペクトルのエアギャップ依存性。

（2）テラヘルツ波ホーンアンテナ（原著論文 26)

導波路へのテラヘルツ波カプラーとして、 図21(a)に示すホーンアンテナを設計・ 試作した。ホーンアンテナペア(集光・ 取り出し)の入出力特性を図21(b)に示 す。カットオフ周波数は設計通りの $750 \mathrm{GHz}$ であり、 $1 \mathrm{THz} \sim 1.7 \mathrm{THz}$ の間 で、透過率がほぼ $100 \%$ の良好な伝送 特性を確認した。出射部の面積が $0.2 \times 0.05 \mathrm{~mm}^{2}$ と小さく、電界強度を高 めることができる。京都大学グループの 近接場顕微鏡を用いた評価により、ホ ーンアンテナがない場合と比較して約 4 倍の電場の増強がみられた。

また，このカプラーを用いて図21(c) に示すフォトニック結晶導波路の明瞭な テラヘルツ波伝送を確認した(図 21 (d))。しかしながら, ホーンアンテナと導 波路デバイスのアライメントは $0.01 \mathrm{~mm}$ 以下の精度で行う必要があり、クライオ スタットを用いた低温測定では実現が

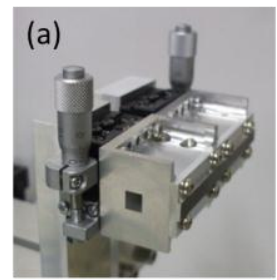

ホーンアンテナ

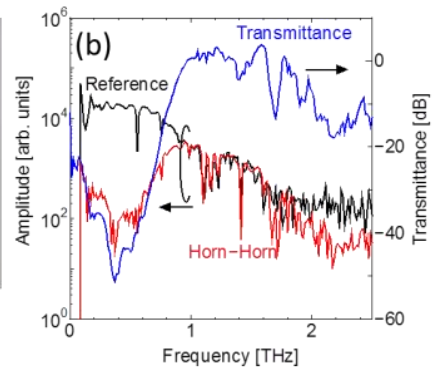

(c)

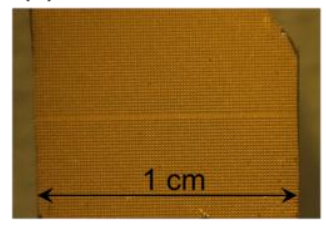

フォトニック結晶導波路

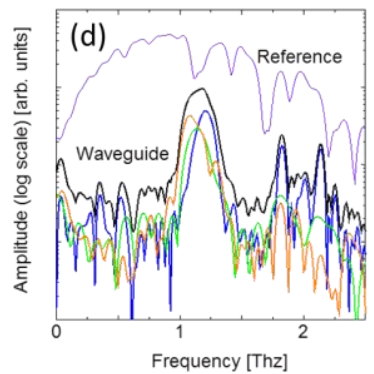

Frequency [Thz]

図21:(a)ホーンアンテナ写真、(b)ホーンアンテ ナ伝送スペクトル、(c)フォトニック結晶導波路 写真、(d)導波路伝送スペクトル。 極めて困難であることが明らかになったため、以下のカプラー・共振器一体型デバイスを開発 することとした。

（3）非対称ブルズアイカプラー一体型テラヘルツ波共振器

量子井戸サブバンド間遷移に起因するテラヘルツ波非線形現象を実現するには、量子井戸 面と垂直な電場が必要であるが、一般的なブルズアイ型カプラーでは試料表面に垂直入射 
する波に対して光軸方向(量子井戸と垂直)な電界成分が得られない。本研究では、集光と 光軸方向成分発生の機能を併せ持つ非対称ブルズアイ構造を考案・作製し(図22(a))、図2 2(b)に示すように、京都大学グループの近接場顕微鏡を用いてテラヘルツ波の波集光・軸方 向電場発生を実証した。また, 量子井戸構造を含む共振器を一体化したデバイス(図 $22(\mathrm{c})$ ) を作製し、京都大学グループの高強度テラヘルツ波光源を用いて非線形現象観測実験を進 めている。シミュレーションにより、図22(d)に示すように、ブルズアイ中心入射波の面内電界 方向を軸方向に変換して、かつ 5 倍の電場が発生できること、共振器内においては 30 倍とな ることを確認した。

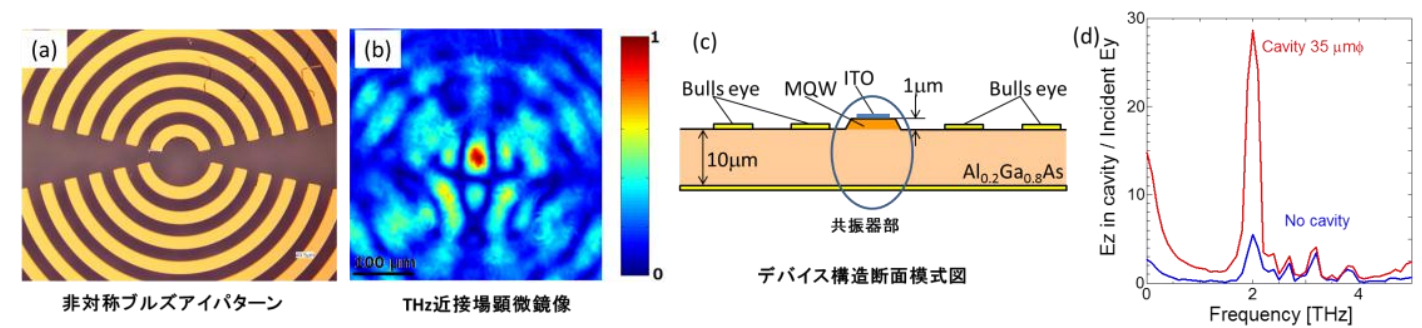

図22:(a)非対称ブルズアイパターン、(b)軸方向電場の近接場顕微鏡写真、(c)ブルズアイ・共 振器一体型デバイス概念図、(d)共振器中心での電界スペクトル。

（まとめ）

テラヘルツ波フォトニック結晶導波路、高効率ホーンアンテナカプラーの実現に成功した。またテ ラヘルツ波を集光し、かつ軸方向電場を発生できる非対称ブルズアイカプラーを考案、実証した。 共振器との組み合わせにより 30 倍の電場増強を予測した。さらに計画に加えて、傾斜位相グレ ーティングによる方向性カプラーを考案した。

III.「早稻田大学」グループ

1. 波長可変高強度テラヘルツ光源開発

(1)研究のねらい

シングルサイクル広帯域高強度テラヘルツ光源と相補的な光源として、波長可变狭帯域テラ ヘルツ光源を開発する。この光源には、以下の特徵が求められる。

(1) 中心周波数が可変であること

(2)パルス長が可変であること

(3) 周波数幅が可変であること

(4)チャープ量が可変であること

(5) 京都大学グループの高強度テラヘルツ波発生技術に適用できること

これらを実現するため、チャープ光パルスをマイケルソン干渉計により干渉させる「チャープ光 パルス干渉法」に着目した。本手法は上記の (1) (2) (5)を満たしている。本研究では、これま で未解明であったチャープ制御理論を確立し、これを実験的に実証することで(3) (4) を達成 し、(1)〜 (5)をすべて満たす波長可変狭帯域テラヘルツ光源を開発する。さらに、開発した 技術を京都大学グループに移転し、同グループの高強度テラヘルツ波発生技術に適用する ことで、波長可変狭帯域高強度テラヘルツ光源を構築し、非摂動論領域のテラヘルツ非線形 実験を展開する。

(2)研究実施方法

早稲田大学グループにおいてチャープ制御理論を確立し、さらに実証実験を実施する。開発 
した技術を京都大学グループに移転し、同グループの高強度テラヘルツ波発生技術に適用 する。

(3)研究成果

(1) 狭帯域テラヘルツパルスのチャープ制御理論の確立（原著論文 29）

チャープ光パルス干涉法におけるテラヘルツパルスのチャープ制御理論を確立した。特に、 パルス拡張器のスペクトル位相とテラヘルツパルスのチャープの関係を定式化した。すなわち、 入カレーザーパルスを中心周波数 $\square 0$ 、時間幅を $\square$ のガウシアンパルスとし、パルス拡張器の スペクトル位相口をレーザーパルスの中心周波数で

$\Phi(\omega)=\Phi^{(1)}\left(\omega-\omega_{0}\right)+\Phi^{(2)}\left(\omega-\omega_{0}\right)^{2}+\Phi^{(3)}\left(\omega-\omega_{0}\right)^{3}$

と展開し、マイケルソン干渉計の時間 遅延をロとしたとき、発生するテラへ ルツパルスは線形にチャープしたが ガウシアンパルスであり、その中心周 波数 $\square \mathrm{T}$ は

$\omega_{T}=-1 /\left(2 \Phi^{(2)}\right)$

チャープの周波数掃引レートは

$-3 \Phi^{(3)} \omega_{T} /\left(2 \Phi^{(2) 2}\right)$

で与えられる。

さらに、回折格子をパルス拡張器とし て用いた実験において、本理論の妥 当性を実証した。実験結果を図24に 示す。

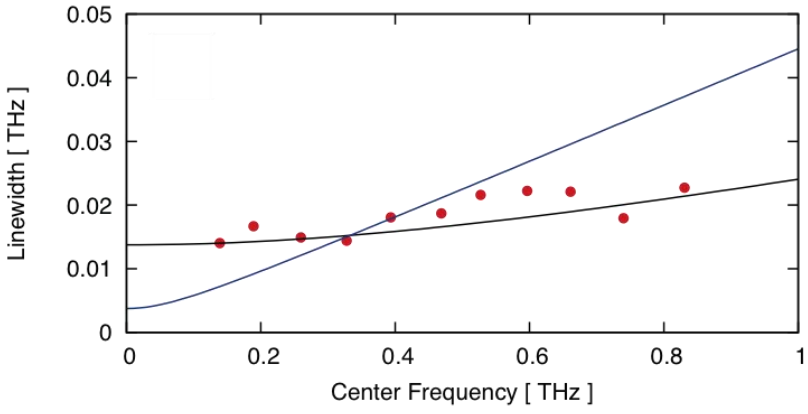

図24 回折格子をパルス拡張器として用いて発生 させた狭帯域テラヘルツパルスの線幅と中心周波 数の関係。赤丸が実験結果、黒線が理論、青線が 先行研究に対応する結果。

(2) 光ファイバーを用いたフーリエ限界テラヘルツパルスの発生（原著論文 27,32）

上記 (1)で確立した理論により、回折格子対

を用いた場合には、テラヘルツ波のチャープ

量に対して回折格子対のパラメータによらな い下限が存在し、フーリエ限界パルスを得る ことが原理的に不可能であることを明らかに した。さらに、分散が適切に制御された単一 モード光ファイバーを光パルス拡張器に用い ることで、フーリエ限界パルスを得ることが可 能であることを理論的に示すとともに、市販の 単一モード光ファイバーを用いた実験により、 回折格子対の下限を超えてチャープの抑制 されたテラヘルツ波の発生を実現した。実験 結果を図25に示す。

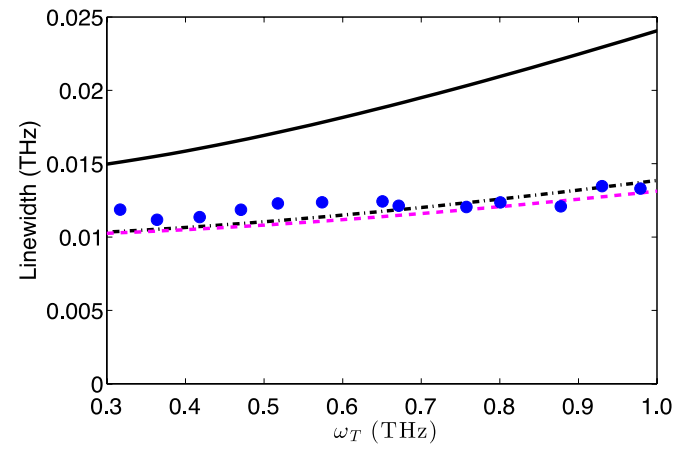

図25 単一モード光ファイバーをパルス拡 張器として用いて発生させた狭帯域テラへ ルツパルスの線幅と中心周波数の関係

(3)強くチャープしたテラヘルツパルスの発生

(原著論文 31,33)

光パルス拡張器として回折格子対を用いることで、回折格子対のパラメータを介してテラヘル ツ波のチャープを自在に制御できることを理論的に示すとともに、チャープが自在に制御され たテラヘルツパルス発生を実験的に実現した。図26に実際に発生したテラヘルツパルスのス ペクトログラムと、 2 つの時刻における短時間フーリエ変換スペクトルの例を示す。 
(4) 2 対の回折格子対を用いたフーリエ限界テラヘル ツパルスの発生(原著論文 38)

内部レンズを有する回折格子対を用いることで正 にチャープしたテラヘルツパルスが発生できること を理論と実験で示すとともに、これと内部レンズを 有さない回折格子対とを組み合わせることで、テラ ヘルツパルスのチャープの原因となる3次のスペク トル位相を相殺し、フーリエ限界テラヘルツパルス の発生が可能であることを実験で実証した。

（まとめ）

チャープパルス干渉法による波長可変狭帯域 テラヘルツ波発生法における狭帯域テラヘル ツパルスのチャープ制御理論を構築し、実験に より実証した。特に、光パルス拡張器しして単一 の回折格子対を用いた場合には、フーリエ限 界パルスを得ることが原理的に不可能であるこ と、分散が適切に制御された単一モード光ファ
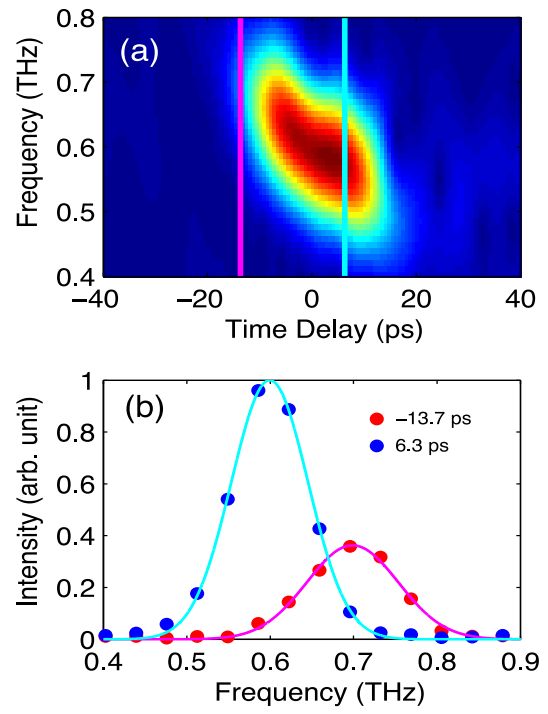

図26（a）負に強くチャープしたテラ ヘルツパルスのスペクトログラム (b) 時刻 -13.7 ps, 6.3 ps における(a)の 短時間フーリエ変換スペクトル イバーを用いることで、フーリエ限界パルスが得 られることを理論的に示すとともに、実験により実証した。さらに、回折格子対を用いること で、回折格子対のパラメータを介してテラヘルツ波のチャープを自在に制御できることを理 論的に示すとともに、チャープが自在に制御されたテラヘルツパルス発生を実験的に実現 した。さらに、2対の回折格子対を用いることで、フーリエ限界パルスが得られることを理論 的に示すとともに、実験により実証した。

2. 微小共振器一量子ドット結合系のテラヘルツ精密分光とコヒーレント制御

(1)研究の永らい

可視〜近赤外領域の高 $\mathrm{Q}$ 值微小共振器と単一量子ドットが結合した系を用いて、単一量子ド ット内部状態の精密分光とコヒーレント制御を目指す。

(2)研究実施方法

可視〜近赤外領域において高いQ值を持つトロイド型微小共振器、および高透過率を持つ サブ波長径テーパーファイバーを作製する。これらを用 いることで、光領域での高効率集光を実現し、テラヘル ツ光による量子ドットの発光過程の制御への応用を目 指す。

(3)得られた成果

(1) 高 $\mathrm{Q}$ 值微小共振器・超低損失テーパーファイバーの 作製（原著論文 5 ）

99\%以上の透過率を持つサブ波長径のテーパーファイ バーと、 $3 \times 10^{8}$ 以上の $\mathrm{Q}$ 值を持つトロイド型微小共振器 を作製し、さらにクライオスタット内でのテーパーファイ バーと単一量子ドットの結合に成功した。この系はテー パーファイバーの Purcell 効果により、高 NA 対物レン ズを凌駕する効率で単一量子ドットの発光を単一モー ドファイバーへ集光することが可能である。

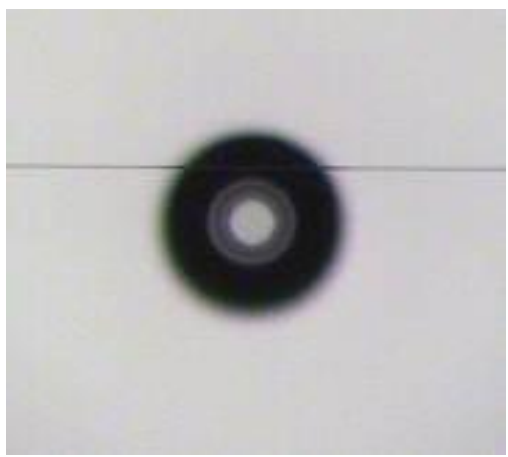

図27作製したトロイド型微小 共振器とテーパーファイバー の光学顕微鏡写真 
(2) 高強度テラヘルツ光による量子ドット発光明滅現象制御に向けた単一量子ドットの精密分光 (原著論文 21)

高強度テラヘルツ光による量子ドット発光明滅現象の制御に向けて、単一量子ドットの精密分 光測定を行った。特に、単一量子ドットの発光明滅現象を観測し、その励起波長依存性を測 定した結果、オン状態とオフ状態の持続時間が従う幕乗則の指数が励起の余剩エネルギー に依存することを見いだした。さらに、この発光明滅現象において、新奇な発光状態を見いだ した。すなわち、高い励起光強度下 $\left(92 \mathrm{~W} / \mathrm{cm}^{2}\right)$ で測定した場合は、オン状態のおよそ半分 の発光強度を有する中間状態が現れ、その発光のピークエネルギーはオン状態よりも 10 $\mathrm{meV}$ 程度低エネルギー側にシフトしていることが観測された。このシフト量はトリオンの束縛エ ネルギーと同程度であり、光学的励起によるトリオン形成を示唆している。

(まとめ)

高強度テラヘルツ光による量子ドットの内部量子状態や発光過程の制御に向けて、光領域での高 効率集光のためのデバイスを作製した。さらに、高強度テラヘルツ光による量子ドット発光明滅現 象の制御に向けて、単一量子ドットの精密分光測定を行い、発光明滅現象における新奇な発光状 態を発見した。 


\section{$\S 4$ 成果発表等}

（1）原著論文発表 （国際（欧文）誌 38 件）

1. H. Hirori, M. Nagai, and K. Tanaka, "Excitonic Interactions with Intense Terahertz Pulses in ZnSe/ZnMgSSe Multiple Quantum Wells”, Phys. Rev. B 81, 081305(R) (2010). *Editor's suggestion.

2. A. Doi, F. Blanchard, H. Hirori, and K. Tanaka, "Near-field THz imaging of free induction decay from a tyrosine crystal", Opt. Express, 18, 18419 (2010).

3. M. Jewariya, M. Nagai, and K. Tanaka, "Ladder Climbing on the Anharmonic Intermolecular Potential in an Amino Acid Microcrystal via an Intense Monocycle Terahertz Pulse", Phys. Rev. Lett. 105, 203003 (2010).

4. K. Shinokita, H. Hirori, M. Nagai, N. Satoh, Y. Kadoya, and K. Tanaka, "Dynamical Franz-Keldysh effect in GaAs/AlGaAs multiple quantum wells induced by single-cycle terahertz pulses", Appl. Phys. Lett. 97, 211902 (2010).

5. Takao Aoki, "Fabrication of Ultralow-loss Tapered Optical Fibers and Microtoroidal Resonators", Jpn. J. Appl. Phys. 49, 118001 (2010).

6. H. Hirori, A. Doi, F. Blanchard, and K. Tanaka, "Single-cycle terahertz pulses with amplitudes exceeding $1 \mathrm{MV} / \mathrm{cm}$ generated by optical rectification in LiNbO3", Appl. Phys. Lett. 98, 091106 (2011).

7. M. Hishida and K. Tanaka, "Long-range hydration effect of lipid membrane studied by terahertz time-domain spectroscopy", Phys. Rev. Lett. 106, 158102 (2011).

8. F. Blanchard, A. Doi, T. Tanaka, H. Hirori, H. Tanaka, Y. Kadoya, and K. Tanaka, "Real-time terahertz near-field microscope," Opt. Express, 19, 8277 (2011).

9. H. Hirori, K. Shinokita, M. Shirai, S. Tani, Y. Kadoya, K. Tanaka, "Extraordinary carrier multiplication gated by a picosecond electric field pulse", Nature Communications, 2, 594 (2011).

10. Koichiro Tanaka, Hideki Hirori, and Masaya Nagai, "THz Nonlinear Spectroscopy of Solids", IEEE Transactions on Terahertz Science and Technology, 1, 301 (2011).

11. A. Doi, F. Blanchard, T. Tanaka, and K. Tanaka,'Improving spatial resolution of real-time terahertz near-field microscope", Journal of Infrared Millimeter and Terahertz Waves, 32, 1043 (2011).

12. Yosuke Minowa, Masaya Nagai, Hu Tao, Kebin Fan, A. C. Strikwerda, Xin Zhang, Richard D. Averitt, and Koichiro Tanaka, "Extremely thin metamaterial as slab waveguide at terahertz frequencies", IEEE Transactions on Terahertz Science and Technology, 1, 441 (2011).

13. I. Katayama, H. Aoki, J. Takeda, H. Shimosato, M. Ashida, R. Kinjo, I. Kawayama, M. Tonouchi, M. Nagai, and K. Tanaka "Ferroelectric soft mode in a SrTiO3 thin film impulsively driven to the anharmonic regime using intense picosecond terahertz pulses", Phys. Rev. Lett. 108, 097401 (2012).

14. Damien Armand, Gen Taguchi, and Yutaka Kadoya "Mechanical active control of surface plasmon properties", Opt. Express, 20, 9523 (2012).

15. M. Hishida, K. Tanaka, "Transition of the hydration state of a surfactant accompanying structural transitions of self-assembled aggregates", J. Phys.: Condens. Matter, 24, 284113 (2012).

16. Jiro Kitagawa, Mitsuhiro Kodama, and Yutaka Kadoya "Design of Two-Dimensional Low-Dielectric Photonic Crystal and Its Terahertz Waveguide Application”, Jpn. J. Appl. Phys. 51, 062201 (2012).

17. Jiro Kitagawa, Mitsuhiro Kodama, Shingo Koya, Yusaku Nishifuji Damien Armand and Yutaka Kadoya, "THz wave propagation in two-dimensional metallic photonic crystal with mechanically tunable photonic-bands", Opt. 
Express, 20, 17271 (2012).

18. F. Blanchard, K. Ooi, T. Tanaka, A. Doi, and K. Tanaka "Terahertz spectroscopy of the reactive and radiative near-field zones of split ring resonator", Optics Express, 20, 19395 (2012).

19. Shuntaro Tani, Francois Blanchard, and Koichiro Tanaka "Ultrafast Carrier Dynamics Under High Electric Field in Graphene", Phys. Rev. Lett. 109, 166603 (2012).

20. Yuji Hazama, Nobuko Naka, Makoto Kuwata-Gonokami, and Koichiro Tanaka, "Resonant creation of indirect excitons in diamond at the phonon-assisted absorption edge", Europhysics Letters, 104, 47012 (2013)

21. N. Yoshikawa, H. Hirori, H. Watanabe, T. Aoki, T. Ihara, R. Kusuda, C. Wolpert, T. K. Fujiwara, A. Kusumi, Y. Kanemitsu, and K. Tanaka, "Biexciton state causes photoluminescence fluctuations in CdSe/ZnS core/shell quantum dots at high photoexcitation densities", Phys. Rev. B 88, 155440 (2013)

22. Tobias Kampfrath, Koichiro Tanaka and Keith A. Nelson, "Resonant and nonresonant control over matter and light by intense terahertz transients", Nature Photonics 7,680 (2013).

23. K. Shinokita, H. Hirori, K. Tanaka, T. Mochizuki, C. Kim, H. Akiyama, L. N. Pfeiffer and K. W. West, "Terahertz-Induced Optical Emission of Photoexcited Undoped GaAs Quantum Wells", Phys. Rev. Lett. 111, 067401 (2013). *Editor's Suggestion

24. Y. Mukai, H. Hirori, and K. Tanaka, "Electric field ionization of gallium acceptors in germanium induced by single-cycle terahertz pulses", Phys. Rev. B 87, 201202(R) (2013).

25. H. Nishimura, K. Ritchie, R. S. Kasai, N. Morone, H. Sugimura, K. Tanaka, I. Sase, A. Yoshimura, Y. Nakano, T. K. Fujiwara, and A. Kusumi, "Biocompatible fluorescent silicon nanocrystals for single-molecule tracking and fluorescence imaging" The Journal of Cell Biology, 202, 967 (2013).

26. D. Armand, H. Taniguchi, Y. Kadoya, T. Tanaka, and K. Tanaka, "Terahertz full horn-antenna characterization", Appl. Phys. Lett. 102, 141115 (2013).

27. T. Yoshida, S. Kamada, S. Murata, and T. Aoki, "Fiber-based pulse stretcher for narrowband terahertz pulse generation with a chirped-pulse beating method", Appl. Phys. Lett. 103, 151118 (2013).

28. H. Hirori and K. Tanaka, "Nonlinear optical phenomena induced by intense single-cycle terahertz pulses", IEEE Journal of Selected Topics in Quantum Electronics 19, 8401110 (2013).

29. S. Kamada, S. Murata, and T. Aoki, "On the Chirp of Narrowband Terahertz Pulses Generated by Photomixing with Nonlinearly Chirped Laser Pulse Pairs", Appl. Phys. Express 6, 032701 (2013).

30. F. Blanchard, A. Doi, T. Tanaka, and K. Tanaka, "Real-Time, Subwavelength Terahertz Imaging”, Annu. Rev. Mater. Res., 43:11.1 (2013).

31. S. Kamada, T. Yoshida, and T. Aoki, "The chirp-control of frequency-tunable narrowband terahertz pulses by nonlinearly chirped laser pulse beating", Appl. Phys. Lett. 104, 101102 (2014).

32. T. Yoshida, S. Kamada, S. Murata, and T. Aoki, "Suppressing Chirp of $\mathrm{THz}$ Pulses by Using an Optical Fiber as a Pulse Stretcher for Chirped Pulse Beating", JPS Conf. Proc. 1, 014027 (2014)

33. S. Kamada, T. Yoshida, and T. Aoki, "Controlling Chirping of Narrowband $\mathrm{THz}$ Pulses Generated by Non-Linearly Chirped Pulse Beating", JPS Conf. Proc. 1, 014022 (2014).

34. Y. Mukai, H. Hirori, T. Yamamoto, H. Kageyama, and K. Tanaka, "Antiferromagnetic resonance excitation by terahertz magnetic field resonantly enhanced with split ring resonator", Appl. Phys. Lett. 105, 022410 (2014). 
35. F. Blanchard, K. Sumida, C. Wolpert, M. Tsotsalas, T. Tanaka, A. Doi, S. Kitagawa, D. G. Cooke, S. Furukawa, and K. Tanaka, "Terahertz phase contrast imaging of sorption kinetics in porous coordination polymer nanocrystals using differential optical resonator," Opt. Express, vol. 22, 11061-11069 (2014).

36. M. Hishida, K. Tanaka, Y. Yamamura, K. Saito, "Cooperativity between Water and Lipids in Lamellar to Inverted-Hexagonal Phase Transition", J. Phys. Soc. Jpn., 83, 044801 (2014).

37. Y. Onishi, Z. Ren, K. Segawa, M. Lorenc, H. Cailleau, Y. Ando, and K. Tanaka, "Ultrafast carrier relaxation through Auger recombination in the topological insulator Bi1.5Sb0.5Te1.7Se1.3”, Phys. Rev. B 91085306 (2015). selected as an Editor's suggestion

38. T. Yoshida, S. Kamada, and T. Aoki, "Elimination of the chirp of narrowband terahertz pulses generated by chirped pulse beating using a tandem grating pair laser pulse stretcher", Opt. Express 22, 23679-23685 (2014).

doi: 10.1364/OE.22.023679

\section{（2）その他の著作物（総説、書籍など） 11 件}

1. 土井厚志、「テラヘルツ顕微鏡」、書籍「テラヘルツ波新産業」(シーエムシー出版、2011 年発行)

2. 田中耕一郎、タイトル「高輝度テラヘルツ波を用いた非線形分光」、書籍「テラヘルツ波新 産業」(シーエムシー出版、2011年発行)

3. 永井正也、第 3 章テラヘルツ波光源、3-4 角度波面整合放射 (フェムト秒レーザー励起) 3-5 ガスプラズマ 書籍「テラヘルツ波新産業」(シーエムシー出版 2011 年発行)

4. 廣理英基、田中耕一郎、「超高強度テラヘルツ光源の新展開」、掲載誌「オプトロニクス, 30 巻 第 8 号, 頁 86-92, 発表年 2011

5. 田中耕一郎、廣理英基、「高強度テラヘルツ光による非線形光学現象」、掲載誌「固体物 理 第46巻, 11 号、129、発表年 2011

6. 永井正也、廣理英基、田中耕一郎、「高強度テラヘルツパルスが創る物性」、掲載誌「日本 物理学会誌, 66 巻, 第 12 号 919-922, 発表年 2011」

7. 田中耕一郎、「テラヘルツ領域のエバネッセント光をもちいた水溶液の研究」、掲載誌「表 面科学」第 32 巻, 12 号, 785 、発表年 2011

8. 廣理英基, 田中耕一郎, 「高強度テラヘルツパルスで誘起する非線形光学現象」, 応用物 理学会誌, 81 巻 第 4 号, 頁 291-297, 発表年 2012

9. 田中耕一郎, 廣理英基, 「高強度テラヘルツ光発生と非線形テラヘルツ分光」, レーザー 研究, 40 巻 第 7 号, 頁 480-485, 発表年 2012

10. 田中智子, 土井厚志, ブランチャード フランソワ,「リアルタイムテラヘルツ近接場顕微鏡 の開発とその応用」, 分光研究, 61 巻, 第 4 号, 頁 159-162,発表年 2012

11. 田中智子, 土井厚志, ブランチャード フランソワ,「リアルタイムテラヘルツ近接場顕微鏡の 開発」, 応用物理学会誌，82 巻 第2号，頁 158-161, 発表年 2013

（3）＼cjkstart国際学会発表及び主要な国内学会発表

\section{（1) 招待講演 （国内会議 14 件、国際会議 43 件）}

1. 学会名: NATO Advanced Research Workshop on Terahertz and Mid Infrared Radiation: Basic Research and Applications (TERA-MIR 2009)

発表者: M. Jewariya(Kyoto Univ.)

タイト:Large Amplitude anharmonic vibrations driven by monocycle intense

$\mathrm{THz}$ pulse 
場所：Turunç-Marmaris,Turkey

月日：2009/11/03-11/06

2. 学会名: The International Workshop on Terahertz Technology 2009

(TeraTech '09)

発表者：Koichiro Tanaka (Kyoto Univ.)

タイトル: Nonlinear coherent dynamics induced by intense terahertz field

場所：大阪大学 中之島センター、大阪、日本

月日：2009/11/30-12/3

3. 学会名: Asian Conference on Ultrafast Phenomena (ACUP)

発表者: Masaya Nagai (Kyoto Univ.)

タイトル:Intense $\mathrm{THz}$ pulse generation and $\mathrm{THz}$ nonlinear spectroscopy

場所：Taipei , Taiwan

月日：2010/01/13

4. 学会名：1st Ultrafast Dynamics Symposium

発表者： Masaya Nagai (Kyoto Univ.)

タイトル:Large-Amplitude anharmonic vibrations driven by intense $\mathrm{THz}$ pulse

場所：Hsinchu, Taiwan

月日：2010/01/14

5. 学会名：2009 年度第4回研究会「メタマテリアルの開発之応用」

発表者:田中耕一郎 (京都大学)

タイトル:2次元メタマテリアルの表面モード

場所：京都，日本

月日: 2010/01/09

6. 学会名: The 3rd International Workshop on Far-Infrared Technologies 2010

発表者：Koichiro Tanaka (Kyoto Univ.)

タイトル: Terahertz Non-linear Spectroscopy

場所：福井大学 遠赤外領域開発研究センター、福井、日本

月日：2010/03/15-03/17

7. 学会名：2010年春季 第57回 応用物理学関係連合講演会シンポジウム

発表者：田中耕一郎(京都大学)

タイトル:テラヘルツ非線形光学

場所：東海大学 湘南キャンパス、神奈川、日本

月日：2010/03/17-03/20

8. 学会名：日本物理学会 第 65 回年次大会

発表者：永井 正也 (京都大学)

タイトル:高強度テラヘルツ電磁パルス光源の開拓と光物性への応用

場所：岡山大学、岡山、日本

月日：2010/03/20-03/23

9. 学会名：14th East Asian Workshop on Chemical Dynamics

発表者: Masaya Nagai(Kyoto Univ.)

タイトル:Molecules driven by intense $\mathrm{THz}$ pulse

場所： Nara, Japan

月日: $2010 / 05 / 11$

10. 学会名:The Asia Pacific Laser Symposium (APLS)

発表者：Masaya Nagai(Kyoto Univ.)

タイトル: $\mathrm{THz}$ nonlinear spectroscopy with intense monocycle $\mathrm{THz}$ pulse

場所：Jeju island, Korea

月日：2010/05/11-05/15

11. 学会名：The Conference on Lasers and Electro-Optics and The Quantum 
Electronics and Laser Science Conference (CLEO/QELS 2010)

発表者: Ikufumi Katayama(Yokohama National Univ. )

タイトル: Nonlinear THz Spectroscopy on the Dielectric Thin Films

場所：San Jose USA

月日：2010/05/17-05/22

12. 学会名:Advanced Photons and Science Evolution 2010

発表者: Masaya Nagai(Kyoto Univ.)

タイトル:Nonlinearity in terahertz photon physics

場所：Osaka, Japan

月日: 2010/06/14

13. 学会名：17th International Conference on Dynamical Processes in Excited

States of Solids (DPC '10)

発表者: Koichiro Tanaka (Kyoto Univ.)

タイトル: Nonlinear response of exciton transition under intense Terahertz pulse irradiation in ZnSe/ZnMgSSe multi-quantum wells

場所：Argonne National Laboratory, USA

月日：2010/6/20 6/25

14. 学会名: 物性研短期研究会 外部場の時間操作と実時間物理現象

発表者: 永井 正也(京都大学)

タイトル：高強度 $\mathrm{THz}$ 電磁パルスを用いた非線形分光

場所：東京大学物性研 柏、千葉、日本

月日：2010/06/22-06/23

15. 学会名：C-PhoST フォーラム「高強度テラヘルツパルス生成とその利用」

発表者: 永井 正也(京都大学)

タイトル：高強度モノサイクル $\mathrm{THz}$ パルスを用いた水の非線形分光

場所：分子研、岡崎、愛知、日本

月日: 2010/08/24

16. 学会名: 20th international conference on applied electromagnetics and communications (ICECom 2010)

発表者: Koichiro Tanaka (Kyoto Univ.)

タイトル: Dynamic THz near-field Imaging of free induction decay from

tyrosine crystal

場所: Dubrovnik, Croatia

月日: $2010 / 9 / 20-9 / 23$

17. 学会名: エクストリーム・フォト二クス研究シンポジウム

発表者: 永井 正也(京都大学)

タイトル：高強度 $\mathrm{THz}$ パルスによる物質制御

場所：理化学研究所、和光、埼玉、日本

月日: 2010/10/12

18. 学会名: European optical society EOS 2010

発表者： Koichiro Tanaka (Kyoto Univ.)

タイト: Enhancement of carrier scattering rate near the Mott density in photo-excited semiconductors

場所：Paris, France

月日：2010/10/25-10/28

19. 学会名: The International Photonics and Opto Electronics Meetings

(POEM2010)

発表者：Koichiro Tanaka (Kyoto Univ.) 
タイトル: Terahertz Non-Linear Spectroscopy in Solids

場所：Wuhan, China

月日: $2010 / 11 / 3-11 / 5$

20. 学会名：Japan-Korea THz joint symposium

発表者： Koichiro Tanaka (Kyoto Univ.)

タイトル: Terahertz Non-Linear Spectroscopy in Solids

場所：Busan, Korea

月日：2010/12/16-12/17

21. 学会名: International 2nd THz-Bio workshop

発表者：Koichiro Tanaka (Kyoto Univ.)

タイトル: High-power $\mathrm{THz}$ generation and its application

場所：Seoul, Korea

月日：2011/01/19-01/20

22. 学会名：International Workshop on Optical Terahertz Science and Technology 2011

発表者： Koichiro Tanaka (Kyoto Univ.)

タイトル: Terahertz Non-Linear Spectroscopy in Solids

場所：Santa-Barbara, USA

月日: 2011/03/13-03/17

23. 学会名：CLEO Europe 2011

発表者：Koihciro Tanaka (Kyoto Univ.)

タイトル: Nonlinear spectroscopy using intense THz pulses with amplitudes

exceeding $1 \mathrm{MV} / \mathrm{cm}$

場所：Munich, Germany

月日: $2011 / 6 / 17-6 / 20$

24. 学会名：2011 International Symposium on Microwave/Terahertz Science and

Applications (MTSA 2011)

発表者：Koihciro Tanaka (Kyoto Univ.)

タイトル: Recent Developments of Intense THz-Wave Generation and

Nonlinear THz spectroscopy

場所: Nanjing China

月日：2011/6/19-6/21

25. 学会名: THz Science and Technology - the castle meeting -

発表者：Koichiro Tanaka (Kyoto Univ.)

タイト: Physics with high THz fields

場所：Marburg, Germany

月日: 2011/7/3-7/6

26. 学会名：International Symposium on Ultrafast Intense Laser Science 10

発表者：Koichiro Tanaka (Kyoto Univ.)

タイトル: High Power THz Wave Generatioon and Its Application to Nonlinear

Spectroscopy

場所：Hotel auf der Wartburg, Eisenach, Germany

月日：2011/10/16-10/20

27. 学会名: Super Imaging 2011

発表者：Koichiro Tanaka (Kyoto Univ.)

タイトル: Terahertz Nearfield Imaging

場所: Hamamatsu Japan

月日: 2011/12/12

28. 学会名：2012 Photonics West, BiOS 2012 
発表者：Koichiro Tanaka (Kyoto Univ.)

タイト: Long-range hydration effect of lipid membrane studied by terahertz time-domain spectroscopy

場所： The Moscone Center, San Francisco, USA

月日: 2012/01/21-26

29. 学会名：2012 Photonics West, LASE 2012

発表者: Hideki Hirori (Kyoto Univ.)

タイトル: Single-cycle terahertz pulses with amplitudes exceeding $1 \mathrm{MV} / \mathrm{cm}$ generated by optical rectification in LiNbO3 and application to nonlinear optics 場所: The Moscone Center, San Francisco, USA

月日：2012/01/21-26

30. 学会名：レーザー学会学術講演会第32回年次大会

発表者: 廣理英基(京都大学)

タイトル：超高強度 $\mathrm{THz}$ パルスの発生と非線形 $\mathrm{THz}$ 分光への応用

場所：TKP仙台カンファレンスセンター，仙台、宮城、日本

月日：2012/01/30-02/01

31. 学会名：3rd THz-BIO workshop

発表者：Koichiro Tanaka (Kyoto Univ.)

タイト：Terahertz Near-Field Microscope for bio-sensing

場所：Seoul National University, Korea

月日：2012/02/06-02/08

32. 学会名: Gordon Research Conference: Ultrafast Phenomena in Correlated

Systems

発表者: Koichiro Tanaka (Kyoto Univ.)

タイトル Nonlinear transport phenomena driven by intense terahertz electric field

場所：Galvez Hotel, Huston USA

月日：2012/02/19-02/24

33. 学会名: International Forum on Terahertz Spectroscopy and Imaging, 5th

Workshop on Terahertz Technology

発表者: Koichiro Tanaka (Kyoto Univ.)

タイトル: Terahertz Near-field Microscope working at Video Rate

場所: Fraunhofer-Zentrum Fraunhofer Platz 1, Kaiserslautern Germany

月日：2012/03/06-03/07

34. 学会名：テラテク技術討論会

発表者：廣理英基(京都大学)

タイトル：高強度テラヘルツパルスで誘起する非線形光学現象

場所：東京大学本郷キャンパス 工学部2号館第2会議室、東京、日本

月日：2012/03/21

35. 学会名: The 1st Advanced Lasers and Photon Sources (ALPS'12)

発表者：Koichiro Tanaka (Kyoto Univ.)

タイトル: Terahertz Nonlinear Spectroscopy with Intense Half-Cycle Pulses

場所：Pacifico Yokohama Yokohama, Japan

月日：2012/04/26 04/27

36. 学会名: Biophotonics Symposium: Terahertz Waves \& Interactions with

Biological Structures

発表者：Koichiro Tanaka (Kyoto Univ.) 
タイトル: Terahertz Near-Field Microscope for bio-sensing

場所：University of California, Davis, Sacramento, CA, USA

月日：2012/06/29

37. 学会名: The 10 th International Conference on Excitonic Processes in

Condensed Matter, Nanostructured and Molecular Materials (EXCON2012)

発表者: Hideki Hirori (Kyoto Univ.)

タイトル: Extraordinary carrier multiplication induced by single-cycle terahertz

pulses with amplitudes exceeding $1 \mathrm{MV} / \mathrm{cm}$

場所: de Oosterpoort, Groningen, Netherland

月日：2012/07/02-07/06

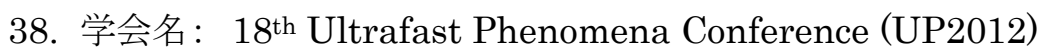

発表者: Koichiro Tanaka (Kyoto Univ.)

タイトル: Nonlinear Terahertz Spectroscopy in Solids with Single-Cycle

Terahertz Pulses

場所: Lausanne, Switzerland

月日：20120/07/09-07/13.

39. 学会名：34 $4^{\text {th }}$ International Free Electron Laser Conference (FEL2012)

発表者：Koichiro Tanaka (Kyoto Univ.)

タイトル: High-Power Terahertz Generation and Terahertz Nonlinear

Spectroscopy

場所：Nara, Japan

月日：2012/08/26-08/31.

40. 学会名：DYCE 公開フォーラム

発表者:田中耕一郎 (京都大学)

タイトル:半導体におけるテラヘルツ非線型伝導

場所：東京大学本郷キャンパス小柴ホール、日本

月日: $2012 / 8 / 6$

41. 学会名: DYCE International Workshop

発表者:Koichiro Tanaka (Kyoto Univ.)

タイトル: Terahertz spectroscopy in solids with single-cycle terahertz pulses

場所：Kussharo, Hokkaido, Japan

月日：2012/08/7-8/11

42. 学会名：37th International Conference on Infrared, Millimeter and Terahertz

Waves (IRMMW-THz2012)

発表者：Koichiro Tanaka (Kyoto Univ.)

タイトル: Nonlinear carrier dynamics induced by intense terahertz wave

場所： University of Wollongong, Wollongong, Australia

月日：2012/09/23-09/28

43. 学会名：2012年 秋季第73回応用物理学会学術講演会

発表者：田中耕一郎 (京都大学)

タイトル：高強度テラヘルツ電磁波を用いた半導体超格子の伝導制御

場所：愛媛大学城北地区、松山大学文京キャンパス、愛媛、日本

月日：2012/09/11-09/14

44. 学会名：日本物理学会 2012 年 秋季大会

発表者: 田中耕一郎(京都大学)

タイトル：高強度テラヘルツ光が拓く非平衡物性科学

場所：横浜国立大学、横浜、日本

月日：2012/09/18-09/21

45. 学会名：International Symposium on Frontiers in THz Technology (FTT 2012) 
発表者：Koichiro Tanaka (Kyoto Univ.)

タイトル: Terahertz Spectroscopy in Solids with Single-Cycle Terahertz Pulses

場所：Nara, Japan

月日：2012/11/27-11/29.

46. 学会名: Nonlinear Optics (NLO2013)

発表者: Hideki Hirori(Kyoto Univ.)

タイトル: High-power Terahertz Pulse Generation and Application to

Nonlinear $\mathrm{THz}$

Spectroscopy

場所:The Fairmont Orchid, Kohala Coast, Hawaii, USA

月日:2013/07/21-07/26

47. 学会名：18th International Conference on Electron Dynamics in

Semiconductors, Optoelectronics and Nanostructures (EDISON18)

発表者: Hideki Hirori(Kyoto Univ.)

タイトル:High-power Terahertz Pulse Generation and Application to Nonlinear

THz Spectroscopy

場所: Kunibiki Messe, Matsue, Japan

月日:2013/07/22-07/26

48. 学会名: 1st WPI Workshop on Materials Science - the 10th France-Japan

Workshop on Nanomaterials

発表者: Koichiro Tanaka (Kyoto Univ.)

タイトル: Terahertz Photonics for Material Science

場所: Kyoto, Japan

月日:2013/07/07

49. 学会名：2013 International Symposium on. Microwave/Terahertz Science and Applications (MTSA 2013)

発表者: Koichiro Tanaka (Kyto Univ.)

タイト: Nonlinear Terahertz Spectroscopy in Semiconductors

場所：Shanghai, China

月日:2013/07/22-07/23

50. 学会名: International Conference on Dynamical Processes in Excited States of Solids (DPC2013)

発表者：Koichiro Tanaka (Kyoto Univ.)

タイトル: Nonlinear Terahertz Spectroscopy in Semiconductors

場所: Fuzhou, China

月日:2013/08/04-08/09

51. 学会名：6th Asian Summer School and Symposium on Laser-Plasma Acceleration and Radiation

発表者: Koichiro Tanaka (Kyoto Univ.)

タイトル: Nonlinear Terahertz Spectroscopy in Semiconductors

場所:Kizu, Japan

月日:2013/09/03-09/06

52. 学会名：10th Conference on Lasers and Electro-Optics Pacific Rim (CLEO-PR 2013)

発表者：Koichiro Tanaka (Kyoto Univ.)

タイト:Terahertz Nonlinear Spectroscopy

場所: Kyoto, Japan

月日:2013/06/30

53. 学会名：21st International Conference on Applied Electromagnetics and Communications (ICECom2013) 
発表者：Koichiro Tanaka (Kyoto Univ.)

タイトル Nonlinear Terahertz Spectroscopy in Dirac Electron System

場所:Dubrovnik, Croatia

月日:2013/10/14-10/16

54. 学会名: Swiss-Kyoto Symposium

発表者：Koichiro Tanaka (Kyoto Univ.)

タイトル: Transient spin polarized current induced by femtosecond pulse excitation in topological insulators

場所:Zurich, Switzerland

月日:2013/11/21-11/22

55. 学会名：Gordon Research Conferences on Ultrafast Phenomena in Cooperative System

発表者: Koichiro Tanaka (Kyoto Univ.)

タイトル: Introduction to Structural Transitions and Molecular Materials

Session

場所:Ventura, USA

月日:, Feb. 2-5, 2014.

56. 学会名：日本物理学会 第 69 回年次大会

発表者：谷峻太郎(京都大学)

タイトル：グラフェンのテラヘルツ限界駆動

場所：東海大学 湘南キャンパス、神奈川、日本

月日:2014/03/27-03/28

57. 学会名:応用物理学会 第 61 回応用物理学会春季学術講演会 発表者:廣理英基(京都大学)

タイトル:超高強度 $\mathrm{THz}$ 光源の開発と $\mathrm{THz}$ 非線形分光

場所: 青山学院大学 相模原キャンパス、神奈川、日本

月日:2014/03/17-03/20

(2)口頭発表 （国際会議 36 件）

（国内会議に関しては省略し、国際会議のみ記載した。）

1. 学会名: The Asia Pacific Laser Symposium (APLS), APLS 2010

発表者： Masaya Nagai(Kyoto Univ.)

タイト： Nonlinear transmission spectroscopy of amino acid microcrystals using intense monocycle $\mathrm{THz}$ pulse

場所：Jeju island, Korea

月日：2010/05/14

2. 学会名: The Conference on Lasers and Electro-Optics and The Quantum

Electronics and Laser Science onference (CLEO/QELS 2010)

発表者： Masaya Nagai(Kyoto Univ.)

タイトル: THz Nonlinearity of Water Observed with Intense $\mathrm{THz}$ Pulses

場所：San Jose, USA

月日：2010/5/17-10/22

3. 学会名: The Conference on Lasers and Electro-Optics and The Quantum

Electronics and Laser Science onference (CLEO/QELS 2010)

発表者: Hideki Hirori (Kyoto Univ.)

タイト: Nonperturbative Excitonic Interaction with Intense THz Pulses in

ZnSe/ZnMgSSe Multiple Quantum Wells 
場所：San Jose, USA

月日：2010/05/17-05/22

4. 学会名: International conference on excitonic and photonic processes in condensed and nano materials

発表者: Shuntaro Tani (Kyoto Univ.)

タイトル: Enhancement of carrier scattering rate near the Mott density in

photo-excited semiconductors

場所：Brisbane, Australia

月日：2010/07/11-07/16

5. 学会名：35th International Conference on Infrared, Millimeter, and Terahertz Waves (IRMMW/THz2010)

発表者: Masaya Nagai (Kyoto Univ.)

タイトル: Water molecules driven by intense $\mathrm{THz}$ pulses

場所: Rome, Italy

月日：2010/09/06

6. 学会名: European optical society EOS 2010

発表者：Koihciro Tanaka (Kyoto Univ.)

タイトル: Enhancement of carrier scattering rate near the Mott density in photo-excited semiconductors

場所：Parc floral de Paris, France

月日：2010/10/25-10/28

7. 学会名: European optical society EOS 2010

発表者: Francois Blanchard(Kyoto Univ.)

タイトル: Dynamic $\mathrm{THz}$ near-field Imaging of free induction decay from tyrosine crystal

場所：Parc floral de Paris, France

月日：2010/10/25-10/28

8. 学会名: International Workshop on Optical Terahertz Science and

Technology 2011

発表者: Francois Blanchard(Kyoto Univ.)

タイトル: Near-field imaging of $\mathrm{THz}$ field enhancement

場所：Santa-Barbara, USA

月日：2011/03/13-03/17

9. 学会名： The conference on Lasers and Electro-Optics (CLEO 2011)

発表者: Hideki Hirori(Kyoto Univ.)

タイトル: Highly Efficient Carrier Multiplication and Bright Exciton

Luminescence under Intense Terahertz Pulse (ポストデッドライン論文に選出)

場所：Baltimore, USA

月日：2011/05/01-05/06

10. 学会名：CLEO Europe 2011

発表者：Atsushi Doi(Olympus corp.)

タイトル: Development of real-time near-field $\mathrm{THz}$ microscope

場所: Munich, Germany

月日：2011/05/22-05/26

11. 学会名：4th International Conference on Photoinduced Phase Transitions

and Cooperative Phenomena (PIPT4)

発表者: Koihciro Tanaka(Kyoto Univ.)

タイトル: Nonequilibrium Fluctuation of Photo-Induced Phase under Steady

Light Irradiation in the Spin Crossover Complex 
場所：Wrocław, Poland

月日：2011/06/28-07/02

12. 学会名:17th International Conference on Electron Dynamics in

Semiconductors, Optoelectronics and Nanostructures (EDISON 17)

発表者: Hideki Hirori(Kyoto Univ.)

タイト： Extraordinary Carrier Multiplication in GaAs MQWs by Intense

Terahertz Pulse Excitation

場所：Santa Barbara(米国)

月日: 2011/08/08-08/12

13. 学会名：17th International Conference on Electron Dynamics in

Semiconductors, Optoelectronics and Nanostructures (EDISON 17)

発表者: Shuntaro Tani (Kyoto Univ.)

タイトル: Enhancement of carrier scattering rate near the Mott density in

photo-excited semiconductors

場所：Santa Barbara, USA

月日：2011/08/08-08/12

14. 学会名：The Pacific Rim Conference on Lasers and Electro-Optics (CLEO-PR)

発表者：Jiro Kitagawa (Hiroshima Univ.)

タイトル: New Design of Terahertz Metallic Photonic Crystal with Mechanically

Tunable Photonic-Band-Gap

場所：Sydney, Australia

月日：2011/08/28-09/01

15. 学会名：36th International Conference on Infrared, Millimeter and Terahertz Waves (IRMMW-THz2011)

発表者：Hideki Hirori (Kyoto Univ.)

タイトル: Extraordinary carrier multiplication in GaAs MQWs induced by

intense terahertz pulse

場所：Huston, USA

月日：2011/10/03-10/07

16. 学会名：36th International Conference on Infrared, Millimeter and Terahertz Waves (IRMMW-THz2011)

発表者： F. Blanchard (Kyoto Univ.)

タイトル: Near-field THz imaging of a split ring resonator matrix

場所: Houston, USA

月日：2011/10/03-10/07

17. 学会名：36th International Conference on Infrared, Millimeter and Terahertz

Waves (IRMMW-THz2011)

発表者: Damien Armand (Hiroshima Univ.)

タイトル: Controlling the Surface Plasmon Extension

場所: Houston, USA

月日：2011/10/03-10/07

18. 学会名：36th International Conference on Infrared, Millimeter and Terahertz

Waves (IRMMW-THz2011)

発表者: Yu Mukai (Kyoto Univ.)

タイトル: Non-linear Terahertz Spectroscopy of Accepters in p-Ge

場所: Houston, USA

月日：2011/10/03-10/07

19. 学会名：36th International Conference on Infrared, Millimeter and Terahertz Waves (IRMMW-THz2011)

発表者：Shuntaro Tani (Kyoto Univ.) 
タイトル: Terahertz-wave induced near-infrared transparency in Graphene

場所: Houston, USA

月日：2011/10/03-10/07

20. 学会名: GCOE Symposium 2011

発表者: Shuntaro Tani (Kyoto Univ.)

タイト: Quest for Extreme Terahertz Nonlinear Optics: on Dirac Fermions in

Graphene

場所：Kyoto, Japan

月日： $2012 / 02 / 13 \sim 02 / 15$

21. 学会名: 3rd EOS Topical Meeting on Terahertz Science \& Technology (TST 2012)

発表者: Shuntaro Tani (Kyoto Univ.)

タイトル:Ultrafast Carrier Transport in Graphene under High Electric Field

場所：Prague, Czech Republic

月日：2012/06/17-06/20

22. 学会名：3rd EOS Topical Meeting on Terahertz Science \& Technology (TST 2012)

発表者: Keisuke Shinokita (Kyoto Univ.)

タイトル:Dynamics of Optically Excited Carriers under Intense Terahertz Pulse in

GaAs Multiple Quantum Wells

場所：Prague, Czech Republic

月日：2012/06/17-06/20

23. 学会名：3rd EOS Topical Meeting on Terahertz Science \& Technology (TST 2012)

発表者：Yu Mukai (Kyoto Univ.)

タイトル:Terahertz Electric Field Induced Tunnel Ionization of p-type

Germanium

場所：Prague, Czech Republic

月日：2012/06/17-06/20

24. 学会名：3rd EOS Topical Meeting on Terahertz Science \& Technology (TST 2012)

発表者: Tomoko Tanaka (Kyoto Univ.)

タイトル:Near-field terahertz imaging of a defect in split ring resonator

場所：Prague, Czech Republic

月日：2012/06/17-06/20

25. 学会名：3rd EOS Topical Meeting on Terahertz Science \& Technology (TST 2012)

発表者：Shingo Miyamoto (Hiroshima Univ.)

タイトル:Direct measurement of local $\mathrm{THz}$ electric field and its enhancement in the gap of dipole antennas

場所：Prague, Czech Republic

月日：2012/06/17-06/20

26. 学会名：12th Asia Pacific Physics Conference of AAPPS

発表者： Shohei Kamada (Waseda Univ.)

タイトル:Controlling chirping of narrowband $\mathrm{THz}$ pulses generated by

non-linearly chirped pulse beating

場所: Chiba, Japan

月日:2013/07/14-07/19

27. 学会名：International Workshop on Optical Terahertz Science and Technology 2013(OTST2013) 
発表者: Hideki Hirori (Kyoto Univ.)

タイト: Dynamics of Optically Excited Carriers under Intense Terahertz

Pulse in GaAs Quantum Wells

場所: Kyoto Terssa, Japan

月日:2013/04/01-04/05

28. 学会名： International Workshop on Optical Terahertz Science and Technology 2013(OTST2013)

発表者: Tomoko Tanaka (Kyoto Univ.)

タイト: Terahertz Near-field Microscopic Analysis of Mouse Keratinocytes

場所: Kyoto Terssa, Japan

月日:2013/04/01-04/05

29. 学会名:International Workshop on Optical Terahertz Science and Technology 2013(OTST2013)

発表者:Atsushi Doi (OLYMPUS)

タイトル: Observation of living adipocytes by terahertz near-field microscope

場所: Kyoto Terssa, Japan

月日:2013/04/01-04/05

30. 学会名:International Multidisciplinary Microscopy Congress (InterM2013)

発表者:Tomoko Tanaka (Kyoto Univ.)

タイトル:THz near-field microscope for cell imaging

場所:Antalya, Turkey

月日:2013/10/10-10/13

31. 学会名: $4^{\text {th }}$ International Symposium on Terahertz Nanoscience

発表者: Shuntaro Tani (Kyoto Univ.)

タイト: High field dynamics of Dirac electrons in graphene

場所: Osaka, Japan

月日:2014/03/13-03/14

32. 学会名:CLEO-PR \& OECC/PS 2013

発表者：Keisuke Shinokita (Kyoto Univ.)

タイトル:Photoluminescence Flash Induced by Intense Single-Cycle Terahertz

Pulses in Undoped GaAs Quantum Wells

場所: Kyoto International Conference Center, Kyoto, Japan

月日:2013/06/30-07/04

33. 学会名:International Multidisciplinary Microscopy Congress (INTERM2013)

発表者:Tomoko Tanaka (Kyoto Univ.)

タイトル:THz near-field microscope for cell imaging.

場所: Antalya, Turkey

月日: $2013 / 10 / 10 \sim 10 / 13$

34. 学会名：4th EOS Topical Meeting on Terahertz Science \& Technology (TST2014) 発表者:Tomoko Tanaka (Kyoto Univ.)

タイトル:Terahertz Near-field Imaging for Fractal Metallic Structures

月日:2014/05/12 05/12

35. 学会名：4th EOS Topical Meeting on Terahertz Science and Technology (TST2014)

発表者：Damien Armand (Hiroshima Univ.)

タイトル:Bullseye with broken symmetry for coupling free space radiation to 
cylindrical substrate's mode

場所: Camogli, Italy

月日：2014/05/11 05/14

36. 学会名:4th EOS Topical Meeting on Terahertz Science and Technology (TST2014)

発表者:有川 敬 (京都大学)

タイトル:Terahertz-induced electron localization in a quantum Hall system

場所：Camogli, Italy

月日：2014/05/11 05/14

(3) ポスター発表（国際会議 40 件）

（国内会議に関しては詳細を省略し、国際会議のみ記載した。）

1. 学会名: International Workshop on Terahertz Technology (TeraTech'09)

発表者：Jewaria Mukesh (Kyoto Univ.)

タイトル: Nonlinear transmission spectroscopy of amino acids microcrystals

using a high power monocycle $\mathrm{THz}$ pulse

場所： Osaka, Japan

月日: 2009/11/30-12/03

2. 学会名: International Workshop on Terahertz Technology (TeraTech'09)

発表者: Hideki Hirori (Kyoto Univ.)

タイトル: Crossover of excitonic interaction with terahertz electric field from perturbative to nonperturbative regime

場所: Osaka, Japan

月日: 2009/11/30-12/03

3. 学会名: International Workshop on Terahertz Technology (TeraTech'09)

発表者: Atsushi Doi (OLYMPUS)

タイトル: Real-time near-field imaging of crystalline tyrosine blinking with terahertz free-induction-decay

場所: Osaka, Japan

月日：2009/11/30-12/03

4. 学会名: The 7th Asia-Pacific Laser Symposium(APLS2010)

発表者：Keisuke Shinokita (Kyoto Univ.)

タイト：Dynamical Franz-Keldysh Effect in GaAs Induced by Monocycle

Terahertz pulse

場所：Jeju island, Korea

月日：2010/05/11-05/15

5. 学会名: International Soft Matter Conference 2010

発表者: Mafumi Hishida (Kyoto Univ.)

タイトル: Confined water in lamellar phase studied by $\mathrm{THz}$ time-domain spectroscopy on fully hydrated phospholipid bilayers

場所：Granada Exhibition and Conference Centre, Granada, Spain

月日：2010/07/05-07/08

6. 学会名: International Symposium on Non-Equilibrium Soft Matter 2010

発表者: Mafumi Hishida (Kyoto Univ.)

タイトル: Global hydration state of phospholipid bilayer studied by $\mathrm{THz}$

time-domain spectroscopy

場所：Nara Prefectural New Public Hall, Nara

月日：2010/8/17-8/20 
7. 学会名: Coherent Multi-Dimensional Spectroscopy 2010

発表者： Koichiro Tanaka (Kyoto Univ.)

タイトル: Ladder Climbing on the Anharmonic Intermolecular Potential in

Amino-Acid Microcrystals with Intense Monocycle THz Pulse

場所: Minneapolis, USA

月日: $2010 / 8 / 17-8 / 20$

8. 学会名: 35th international conference on infrared, Millimeter and Terahertz

Waves(IRMMW-THz 2010)

発表者: Keisuke Shinokita(Kyoto Univ.)

タイトル: Dynamical Franz-Keldysh Effect in GaAs Induced by Monocycle

Terahertz pulse

場所：Rome, Italy

月日：2010/09/05-09/11

9. 学会名：35th International Conference on Infrared, Millimeter, and Terahertz

Waves

発表者: Hideaki Tanaka (Hiroshima Univ.)

タイトル:Enhancement of THz field in a gap of dipole antenna

場所: Rome, Italy

月日: 2010/9/05-09/11

10. 学会名： 8th iCeMS International Synposium "Meso-Control of Functional Architectures"

発表者: Mafumi Hishida (Kyoto Univ.)

タイトル: Long-range hydration state of phospholipid bilayer studied by $\mathrm{THz}$

time-domain spectroscopy

場所：Kyoto University, Japan

月日：2010/11/9-11/11

11. 学会名：8th iCeMS International Synposium "Meso-Control of Functional

Architectures"

発表者: Hideki Hirori (Kyoto Univ.)

タイトル: Terahertz nonlinear spectroscopy on single quantum dots

場所：Kyoto University, Japan

月日：2010/11/9-11/11

12. 学会名: International 2nd THz-Bio workshop

発表者: Francois Blanchard (Kyoto Univ.)

タイトル: Near-field imaging of $\mathrm{THz}$ field enhancement

場所：Seoul, Korea

月日：2011/01/19-01/20

13. 学会名：International Workshop on Optical Terahertz Science and Technology

2011(OTST2011)

発表者：Tomoko Tanaka (Kyoto Univ.)

タイトル: Spectroscopic imaging of micro-crystals using real-time $\mathrm{THz}$

near-field microscope

場所：University of California, Santa Barbara, USA

月日: 2011/03/13-03/17

14. 学会名： THz Science and Technology-Castle Meeting-

発表者: Tomoko Tanaka (Kyoto Univ.)

タイトル: Real-time THz Near-Field Microscope

場所：Marburg, Germany

月日：2011/07/03-07/06 
15. 学会名：THz Science and Technology-Castle Meeting-

発表者: Shuntaro Tani (Kyoto Univ.)

タイトル: Terahertz-Wave Induced Near-Infrared Transparency in Graphene

場所: Marburg, Germany

月日：2011/07/03-07/06

16. 学会名：TeraNano PIRE Kick-Off Meeting

発表者: Hideki Hirori (Kyoto Univ.)

タイトル: THz Pulse Induced Photoluminescence from GaAs Multiple Quantum Wells

場所：Rice University, Huston USA

月日：2011/10/07

17. 学会名：17th International Conference of Electron Dynamics in

Semiconductors

発表者: Koichiro Tanaka (Kyoto Univ.)

タイトル: Terahertz field ionization of acceptors in p-Ge, Optoelectronics and

Nanostructures

場所：Houston, TX, USA

月日: 2011/07/03-07/06

18. 学会名：International Symposium on Terahertz Nanoscience (TeraNano 2011)

発表者: Shuntaro Tani (Kyoto Univ.)

タイトル:Terahertz-wave induced near-infrared transparency in Graphene

場所：Osaka, Japan

月日：2011/11/24-11/29

19. 学会名：International Symposium on Terahertz Nanoscience (TeraNano 2011)

発表者：Keisuke Shinokita (Kyoto Univ.)

タイト: Dynamics of Optically Excited Carriers under Intense Terahertz

Pulse in GaAs Multiple Quantum Wells

場所: Osaka, Japan

月日: 2011/11/24-11/29

20. 学会名：Gordon Research Conference: Ultrafast Phenomena in Correlated

Systems

発表者: Hideki Hirori (Kyoto Univ.)

タイトル: Extraordinary Carrier Multiplication Gated by a Picosecond Electric

Field Pulse

場所：Galvez Hotel, Huston USA

月日：2012/02/19-02/24

21. 学会名：3rd EOS Topical Meeting on Terahertz Science and Technology

(TST2012)

発表者：Damien Armand (Hiroshima Univ.)

タイトル: Photonic crystal between metallic parallel plates, effect of air gap on

band structure

場所: Prague, Czech Republic

月日: 2012/06/17-06/20

22. 学会名：3rd EOS Topical Meeting on Terahertz Science and Technology

(TST2012)

発表者：Damien Armand (Hiroshima Univ.)

タイトル: Horn antenna in $\mathrm{THz}$ regime

場所: Prague, Czech Republic

月日：2012/06/17-06/20 
23. 学会名:the 10 $10^{\text {th }}$ International Conference on Excitonic Processes in Condensed Matter, Nanostructured and Molecular Materials (EXCON2012)

発表者:Francois Blanchard (Kyoto Univ.)

タイトル:Near-field terahertz imaging of a defect in split ring resonator

場所：de Oosterpoort, Groningen, Netherland

月日：2012/07/02-07/06.

24. 学会名：38th International Conference on Infrared, Milimeter and Terahertz Waves (IRMMW-THz2013)

発表者: Damien Armand (Hiroshima Univ.)

タイト: Photonic Crystal Sandwiched In Parallel Plates As THz Waveguide

場所: Mainz, Germany

月日：2013/09/14-09/19

25. 学会名: International Workshop on Optical Terahertz Science and Technology 2013(OTST2013)

発表者: Shohei Kamada (Waseda Univ.)

タイトル: Effect of cubic spectral phase of pulse stretcher in narrow-band terahertz pulse generation by chirped-pulse beating

場所：Kyoto Terssa, Japan

月日：2013/04/01-04/05

26. 学会名：12th Asia Pacific Physics Conference of AAPPS

発表者: Tetsuya Yoshida (Waseda Univ.)

タイトル: Suppressing chirp of $\mathrm{THz}$ pulses by using an optical fiber as a pulse stretcher for chirped pulse beating

場所: Chiba, Japan

月日：2013/07/14-07/19

27. 学会名： International Workshop on Optical Terahertz Science and Technology 2013(OTST2013)

発表者： Shuntaro Tani (Kyoto Univ.)

タイトル: Nonlinear Current Induced by Strong Terahertz-wave Irradiation in Graphene

場所：Kyoto Terssa, Japan

月日：2013/04/01-04/05

28. 学会名： International Workshop on Optical Terahertz Science and Technology 2013(OTST2013)

発表者: Tomohiro Tamaya (Kyoto Univ.)

タイトル: Theory of Carrier Dynamics in graphene under High-intensity

Electric Fields

場所：Kyoto Terssa, Japan

月日：2013/04/01-04/05

29. 学会名: International Workshop on Optical Terahertz Science and Technology 2013(OTST2013)

発表者: Keisuke Shinokita (Kyoto Univ)

タイトル: $\mathrm{THz}$-wave activation of trapped carriers in GaAs multiple quantum wells

場所：Kyoto Terssa, Japan

月日：2013/04/01-04/05

30. 学会名: International Workshop on Optical Terahertz Science and Technology 2013(OTST2013)

発表者： François Blanchard (Kyoto Univ.)

タイトル: Subwavelength terahertz spectroscopy of methanol trapping in 
porous coordination polymer nanocrystals

場所：Kyoto Terssa, Japan

月日：2013/04/01-04/05

31. 学会名： International Workshop on Optical Terahertz Science and Technology 2013(OTST2013)

発表者: Krushna Mavani, (Osaka Univ.)

タイトル: Ultrafast Photo-induced Effect and Corresponding Magnetization of Pr 0.5 Sr 0.5 MnO 3 Thin Film as Investigated by Visible Pump Terahertz

Probe Spectroscopy

場所：Kyoto Terssa, Japan

月日：2013/04/01-04/05

32. 学会名: International Conference on Optics of Excitons in Confined Systems 13th (OECS 13)

発表者: Naotaka Yoshikawa (Kyoto Univ.)

タイトル: Generation of trions in CdSe/ZnS core/shell quantum dots under high-density excitation

場所: Rome, Italy

月日：2013/09/09-09/13

33. 学会名： International Conference on Optics of Excitons in Confined Systems 13th (OECS 13)

発表者： Koichiro Tanaka (Kyoto Univ.)

タイトル: Photoluminescence Flash Stimulated by a Strong Single-Cycle Terahertz Pulse in GaAs Quantum Wells

場所: Rome, Italy

月日：2013/09/09-09/13

34. 学会名: Gordon Reserch Conference (Ultrafast Phenomena in Cooperative Systems)

発表者: Yoshito Onishi (Kyoto Univ.)

タイトル: Transient spin polarized current induced by femtosecond pulse excitation in topological insulators

場所: Ventura, USA

月日：2014/02/02-02/07

35. 学会名: Gordon Reserch Conference (Ultrafast Phenomena in Cooperative Systems)

発表者： Shuntaro Tani (Kyoto Univ.)

タイトル: Ultrafast Carrier Dynamics In Graphene under a High Electric Field

場所：Ventura, USA

月日：2014/02/02-02/07

36. 学会名:Le regroupement québécois sur les matériaux de pointe 発表者:Francois Blanchard (Kyoto Univ.)

タイトル: Subwavelength terahertz spectroscopy of methanol trapping in porous coordination polymer nanocrystals

場所: CENTRE MONT-ROYAL, 2200 RUE MANSFIELD, MONTRÉAL, Canada

月日:2013/5/17

37. 学会名: International Workshop on Optical Terahertz Science and Technology (OTST) 2013

発表者: Shohei Kamada (Waseda Univ.)

タイトル: Effect of cubic spectral phase of pulse stretcher in narrow-band terahertz pulse generation by chirped-pulse beating 
場所：Kyoto, Japan

月日：2013/04/01 04/05

38. 学会名：The 12th Asia Pacific Physics Conference of AAPPS (APPC12)

発表者: Tetsuya Yoshida (Waseda Univ.)

タイトル: Suppressing chirp of $\mathrm{THz}$ pulses by using an optical fiber as a pulse stretcher for chirped pulse beating

場所: Chiba, Japan

月日: $2013 / 07 / 14 \sim 07 / 19$

39. 学会名: International Workshop on Optical Terahertz Science and Technology (OTST2013)

発表者: Damien Armand (Hiroshima Univ.)

タイトル:Characteristics of Efficient Horn-Antenna

場所：京都テルサ

月日：2013/04/01 04/05

40. 学会名: The 38th International Conference on Infrared, Milimeter and Terahertz Waves (IRMMW-THz2013)

発表者：Damien Armand (Hiroshima Univ.)

タイトル:Photonic Crystal Sandwiched In Parallel Plates As THz Waveguide

場所：Mainz, Germany

月日：2013/09/02 09/06

\section{(4) 知財出願}

(1)国内出願（ 11 件）

1. テラヘルツ波発生装置、土井厚志、雙木満、オリンパス株式会社、2010/3/24、 2010-068389

2. 観察装置、土井厚志、雙木満、オリンパス株式会社、2010/3/24、2010-068649

3. イメージング装置、土井厚志、フランソワ ブランシャール、オリンパス株式会社, 京都大 学、2010/10/25、2010-238869.

4. 分析装置および分析方法、土井厚志、フランソワ ブランシャール、オリンパス株式会社、 京都大学、2011/1/18、2011-007474

5. テラヘルツ波発生装置、土井厚志、オリンパス株式会社、2011/10/20、2011-231036

6. イメージング装置、土井厚志、フランソワ ブランシャール、オリンパス株式会社、京都大 学、2011/10/24、2011-232930

7. 観察方法および観察装置、土井厚志、オリンパス株式会社、2012/3/19、2012-061955

8. パルスフロント傾斜光学系及びテラヘルツ波発生装置、土井厚志、オリンパス株式会社、 2012/8/28、2012-187790

9. 観察装置、土井厚志、フランソワ ブランシャール、オリンパス株式会社、京都大学、 2012/3/28、2013-069613

10. 液体及び細胞測定用素子、及びそれを用いた測定装置、土井厚志、オリンパス株式会 社、2012/3/28、2013-069616

11. 観察装置、土井厚志、オリンパス株式会社、2014/1/23、2014-010615

\section{(2)海外出願（ 1 件）}

1. TERAHERTZ WAVE GENERATOR、土井厚志、雙木満、オリンパス株式会社、 2011/3/8、PCT/JP2011/001360、13/636937、US

\section{（5）受賞・報道等}




\section{(1)受賞}

1.2011 Young Researcher Award, Shuntaro Tani, International Symposium on Terahertz Nanoscience (TeraNano 2011), Workshop of International Terahertz Research Network (GDR-I)、November 24, 2011

2.2011 Young Researcher Award, Keisuke Shinokita, International Symposium on Terahertz Nanoscience (TeraNano 2011), Workshop of International, Terahertz Research Network (GDR-I), November 24, 2011

3. 第6回大阪大学近藤賞 (論文賞), “超高強度テラヘルツ光源の開発と非線形光学現象へ の応用”, 廣理英基, 2012 年 4 月 17 日

4.2011 Young Researcher Award, Shuntaro Tani, 3rd EOS Topical Meeting on Terahertz Science and Technology (TST2012), June 17 22, 2012

5. 第 7 回日本物理学会若手奨励賞, “超高強度テラヘルツ光源の開発と非線形光学現象の 観測に関する研究”, 廣理英基, 2013 年 3 月 28 日

* 6. 平成26年度文部科学大臣表彰 科学技術賞 研究部門「高強度テラヘルツ光による物質 の非線形光学応答の研究」, 田中耕一郎, 2014 年 4 月 7 日

7.レーザー学会 論文賞(解説部門), “高強度テラヘルツ光発生と非線形テラヘルツ分光”, 田中耕一郎、廣理英基, 2014 年 4 月 18 日

* 8. 第 6 回ドイツ・イノベーション・アワード•ゴッドフリードワグネル賞 (秀賞), “超高強度テラヘ ルツ光源の開発と非線形光学現象への応用に関する研究”, 廣理英基, 2014 年 6 月 18 日

\section{(2)マスコミ（新聞・ T V等）報道}

1. 原著論文 3.に関連してプレスリリースを京都大学とJST の共同でおこなった。 プレスリリース: (2010 年 11 月 1 日)

「熱を加えずに結晶を柔らかくすることに成功〜高強度テラヘルッ電磁パルスで分子ネットワーク操 作が可能に〜」

http://www.jst.go.jp/pr/announce/20101101/index.html

http://www.icems.kyoto-u.ac.jp/j/pr/2010/11/01-nr.html\#cov

(1) 京都新聞 (2010 年 11 月 2 日) 25 面「熱加えず分子同士の結合緩和 京大教授ら手法開 発」

(2) 日刊工業新聞 (2010 年 11 月 2 日) 24 面「京大、テラヘルツ波照射で結晶を柔らかくするこ とに成功」

(3) External Link EurekAlert! "Softening crystals without heat: Using terahertz pulses to manipulate molecular networks" (2010.11.9)

http://www.eurekalert.org/pub_releases/2010-11/ific-scw110910.php

(4) External Link R\&D Magazine "Softening crystals without heat" (2010.11.9)

http://www.rdmag.com/News/2010/11/General-Science-Physics-Softening-Crystals-W ithout-Heat/

(5) External Link ScienceDaily "Softening Crystals Without Heat: Using Terahertz Pulses to Manipulate Molecular Networks" (2010.11.12)

http://www.sciencedaily.com/releases/2010/11/101109095324.htm

(6) 朝日新聞 ( 2010 年 11 月 16 日) 23 面 
2. 原著論文 9.に関連してプレスリリースを京都大学とJST の共同でおこなった。 プレスリリース: (2011 年 12 月 21 日)

$「 1$ 兆分の 1 秒間の強電場パルス照射により半導体の自由電子数を 1 千倍に増幅:超高速卜 ランジスタや高効率の太陽電池の開発に期待」

http://www.jst.go.jp/pr/announce/20111221/index.html

http://www.icems.kyoto-u.ac.jp/j/pr/2011/12/21-nr.html

(1) 日経産業新聞（2011 年 12 月 22 日）「京大など、半導体にテラヘルツ光照射、自由電子 1000 倍に」

(2) 京都新聞 $(2012$ 年 1 月 10 日)「世界最高強度のテラヘルツ電磁波成功 京大グループ」

(3) 日刊工業新聞 (2012 年 2 月 15 日)「京大、テラヘルツ光で半導体中の自由電子を 1000 倍に」

(4) 朝日新聞 WEB（2012 年 2 月 15 日）

\section{(6) 成果展開事例}

(1)実用化に向けての展開

- JST「A-STEP」事業に採択され、実施し、終了。課題名「高分解能テラヘルツ近接場顕微鏡 の開発」(H22〜24)

\section{(2)社会還元的な展開活動}

- 小学生対象、高校生対象の科学体験セミナーで CREST 研究の一端を説明し、科学への興 味を喚起できている。

・中小企業を対象としたテラヘルツセミナーの講師を 2 回つとめた。

・市民向けの講義を京都大学品川オフィスでおこなった。 


\section{$\S 5$ 最後に}

5 年間にわたって研究を暖かく見守ってくださった領域代表の伊藤正先生をはじめアドバイザー の先生、JST の担当の皆様に大変感謝しております。研究の見直しをフレキシブルに認めいただ き、資金面で多大な応援をいただいた結果、最初の目標を上回る多くの成果を得ることができまし た。この成果は、スタッフ研究者、ポスドク、若い博士課程の学生の積極的な研究への参加なしに は得られませんでした。ここに感謝いたします。

我々の切り開いた研究分野は、現在世界的に非常な勢いでひろがっています。そのなかで、こ のように最先端の研究成果を得られたのは、まさに時機を得た CREST 研究のサポートがあったか らです。最近はすぐに役にたつことを重視する側面がありますが、長期的視野にたつて、先端を果 敢に切り開く基礎的な研究テーマへのサポートは非常に重要です。日本に CREST のような研究 費のシステムがあるのは日本の強みだと思います。今後とも基礎研究へのサポートををよろしくお 願い申し上げます。

○TST2013 国際会議での写真

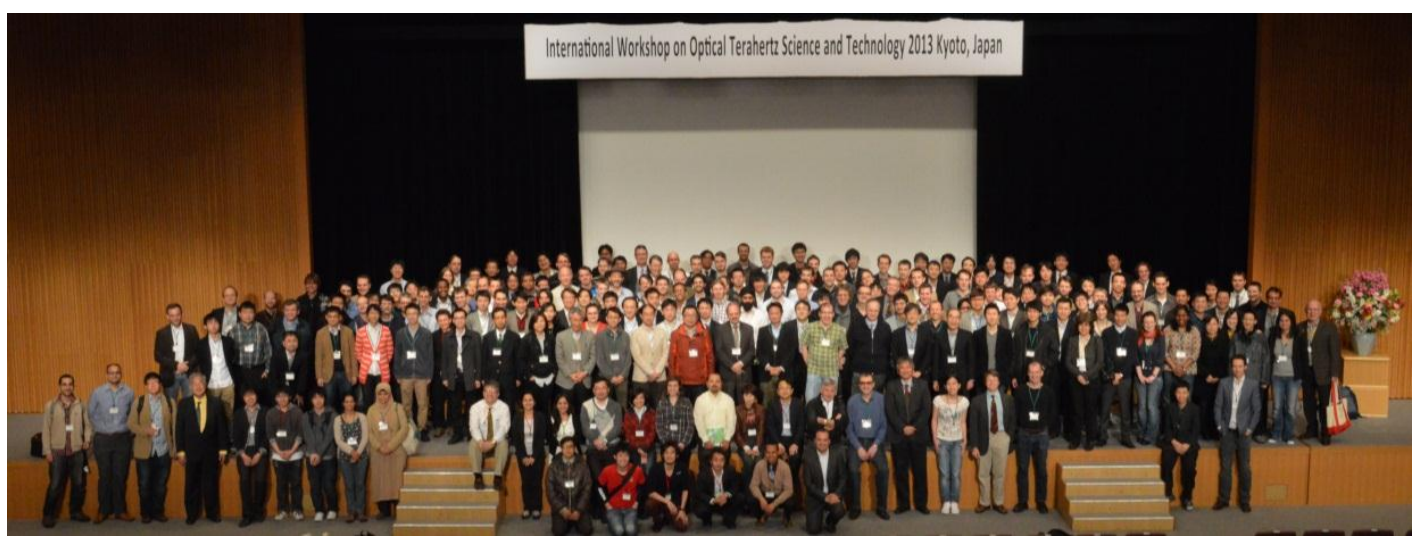

•空気プラズマテラヘルツ光源とテラヘルツ分光システム(矢印が空気プラズマ)

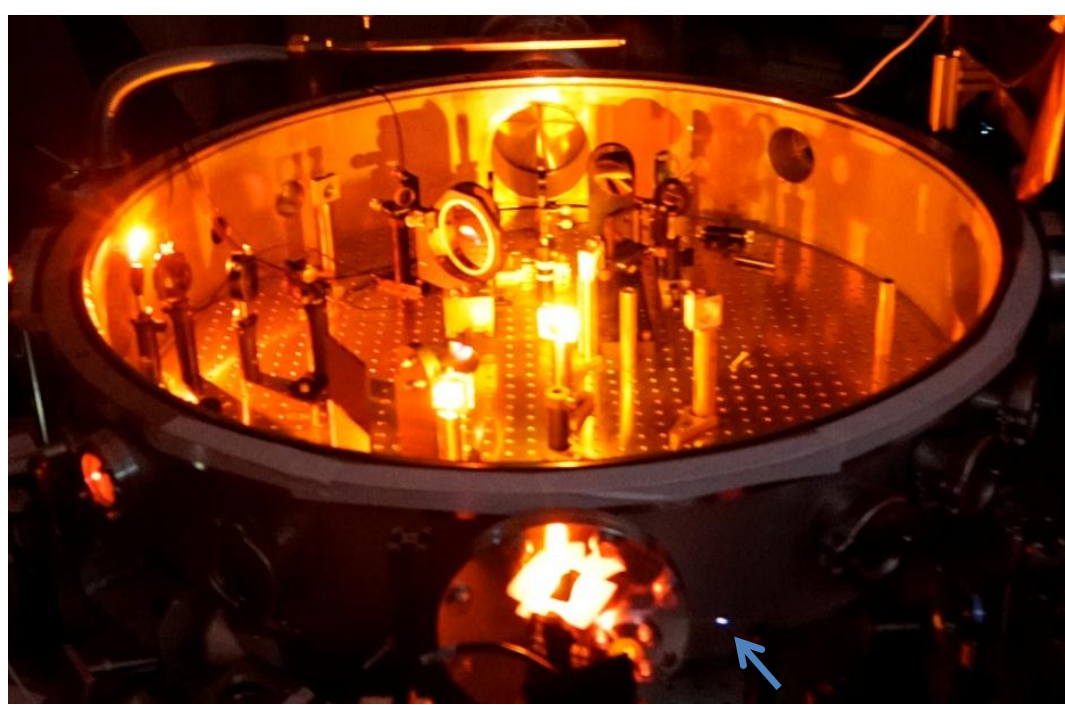

